Cellular Physiology
and Biochemistry and Biochemistry Published online: February 01, 2016

Accepted: November 30, 2015

This article is licensed under the Creative Commons Attribution-NonCommercial-NoDerivatives 4.0 International License (CC BY-NC-ND) (http://www.karger.com/Services/OpenAccessLicense). Usage and distribution for commercial purposes as well as any distribution of modified material requires written permission.

Review

\title{
The Roles of MicroRNA-141 in Human Cancers: From Diagnosis to Treatment
}

\author{
Yanping Gao Bing Feng Siqi Han Kai Zhang Jing Chen Chen Li Rui Wang \\ Longbang Chen
}

Department of Medical Oncology, Jinling Hospital, School of Medicine, Nanjing University, Nanjing, China

\section{Key Words}

MiR-141 • Epithelial-mesenchymal transition • Proliferation • Metastasis • Diagnosis

\begin{abstract}
Cancer remains one of the most threatening causes of human health impairment, and the mechanisms underlying tumorigenesis have not been completely characterized. MicroRNAs (miRNAs) are a group of endogenous, small (18 25 nucleotides) non-coding RNAs which negatively regulate gene expressions by directly binding to the $3^{\prime}$-untranslated regions ( 3 'UTRs) of the target messenger RNAs (mRNAs). Increasing evidence has demonstrated abnormal miRNA profiles and confirmed their involvement in tumor initiation and progression. As one important member of the miR-200 family, microRNA (miR)-141 is aberrantly expressed in many human malignant tumors, participating in various cellular processes including epithelialmesenchymal transition (EMT), proliferation, migration, invasion, and drug resistance. In the present review, we briefly describe the mechanisms underlying miR-141-mediated tumorigenesis and the possible future of miR-141 as a potential diagnostic and prognostic parameter as well as therapeutic target in clinical applications.
\end{abstract}

\section{Introduction}

Human cancers display a high level of heterogeneity, with clinical outcome ranging from spontaneous regression without treatment, to rapid disease progression and mortality. Despite of the development of new chemotherapies and molecular-targeted therapies, most patients experience recurrence, finally, succumb to the disease. Moreover, resistance to anticancer agents increasingly becomes the major clinical obstacle to successful treatment

Y.-P. Gao and B. Feng contributed equally to this work.

Rui Wang, MD and Longbang Chen, MD

KARGER
Department of Medical Oncology, Jinling Hospital, School of Medicine, Nanjing University, Zhongshan East Road No.305 Nanjing, Jiangsu 210002, (China)

Tel.+86-25-80860072, E-Mail wangrui218@163.com and chenlongbang@yeah.net 
of cancer. Therefore it is exigent to exploit novel tumor-targeted therapies with more efficiency and specificity. Over the past decades, mounting evidence has shown that miRNAs are involved in the pathogenesis of cancers as oncogenes or tumor suppressor genes with abnormal expression profiles across various cancer types [1]. Thus, it becomes indispensable to obtain more comprehensive understanding of the specific mechanisms.

MiRNAs are endogenous small non-coding RNAs of 18 25 nucleotides which play imperative regulatory roles in cellular processes through the 3'-UTR binding of the target mRNAs, causing either cleavage or translational repression based on sequence complementarity. MiRNAs are typically excised from 60-110 nucleotide foldback RNA precursor structures, and are now recognized as one of the major regulatory gene families in eukaryotic cells [2]. MiRNAs have emerged as integral components of almost every biological process such as EMT, cell proliferation, migration, differentiation, apoptosis and angiogenesis [3]. Aberrant expression of miRNAs is involved in disease status, cancer, cardiovascular disease, neurodegenerative disease and viral infections [4]. Interestingly, more than $50 \%$ of miRNA genes are frequently located at fragile sites and genomic regions involved in cancers [5]. They also can restrain the expression of important cancer-related genes. Further elucidation of the association between miRNAs and tumorigenesis may contribute to a deeper understanding of cancers and lead to the identification of potential diagnostic and prognostic parameter as well as therapeutic target in clinical applications.

The miR-200 family is composed of miR-200a, miR-200b, miR-200c, miR-141 and miR429 and reported to be associate with the formation of cancer stem cells and regulation of EMT [6]. Among them, the miR-200bc/429 and miR-200a/141 clusters share seed sequences differing in only the fourth nucleotide ( $\mathrm{U}$ to $\mathrm{C}$ ) and are expressed as two separate polycistronic pri-miRNA transcripts [7] (Fig. 1A-B). Over the past decades, disorganized regulation of miR200 family members has been demonstrated in various types of human cancers [8-11]. For example, miR-200a/141 is reported to inhibit migration, invasion, proliferation and drug resistance in head and neck squamous cell carcinoma, non-small cell lung cancer, female reproductive cancers and renal cell carcinoma [12-14], but enhance proliferation and drug resistance in colorectal cancer and ovarian cancer $[15,16]$. MiR-200bc/429 could regulate cell viability, apoptosis, cell cycle progression and EGF-driven invasion in breast cancer cells with distinct patterns from the miR-200a/141 cluster [17]. In a word, miR-141 is commonly dysregulated in malignant tumors, and plays essential roles in tumor development and progression. In this review, we summarize the current research results of the physiology and pathological functions of miR-141 as well as the possible future of these discoveries in clinical applications.

\section{MiR-141 Biogengesis}

In mammals, a miRNA is transcribed by RNA polymerase II from introns of proteincoding genes as a monocistronic or polycistronic long primary transcript named primary miRNA (pri-miRNA) at the 5' end with a 5'-methyl-7-guanosine cap and at the $3^{\prime}$ end with a poly (A) tail [18]. After transcription, pri-miR-141 undergos at least three steps before becoming the mature single-stranded form (Fig. 1C-D). After transcription, pri-miR-141 is cleaved into a stern-loop structure containing $\sim 70$-nt (precursor) pre-miRNAs by the RNase III type endonucleases Drosha,which is a large protein of $\sim 160 \mathrm{kDa}$ combined with its cofactor DiGeorge syndrome critical region gene 8 to form a complex known as the microprocessor complex $[19,20]$. Pre-miR-141 is then exported by exportin-5, one of the Ran-dependent nuclear transport receptors, to the cytoplasm where enzyme Dicer along with its partner TAR (HIV) RNA binding protein removes the loop region from pre-miR-141 and cleaves it into a $\sim 22$-nt double-stranded miRNA duplex. The duplex contains two forms of mature miRNAs and is finally cleaved from either the 5' or 3' arm extending out from the stem loop [21-26]. The mature miR-141 is then bound to argonaute protein to form a miRNA-protein complex known as the RNA-induced silencing complex (RISC), miRNP, or

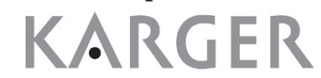




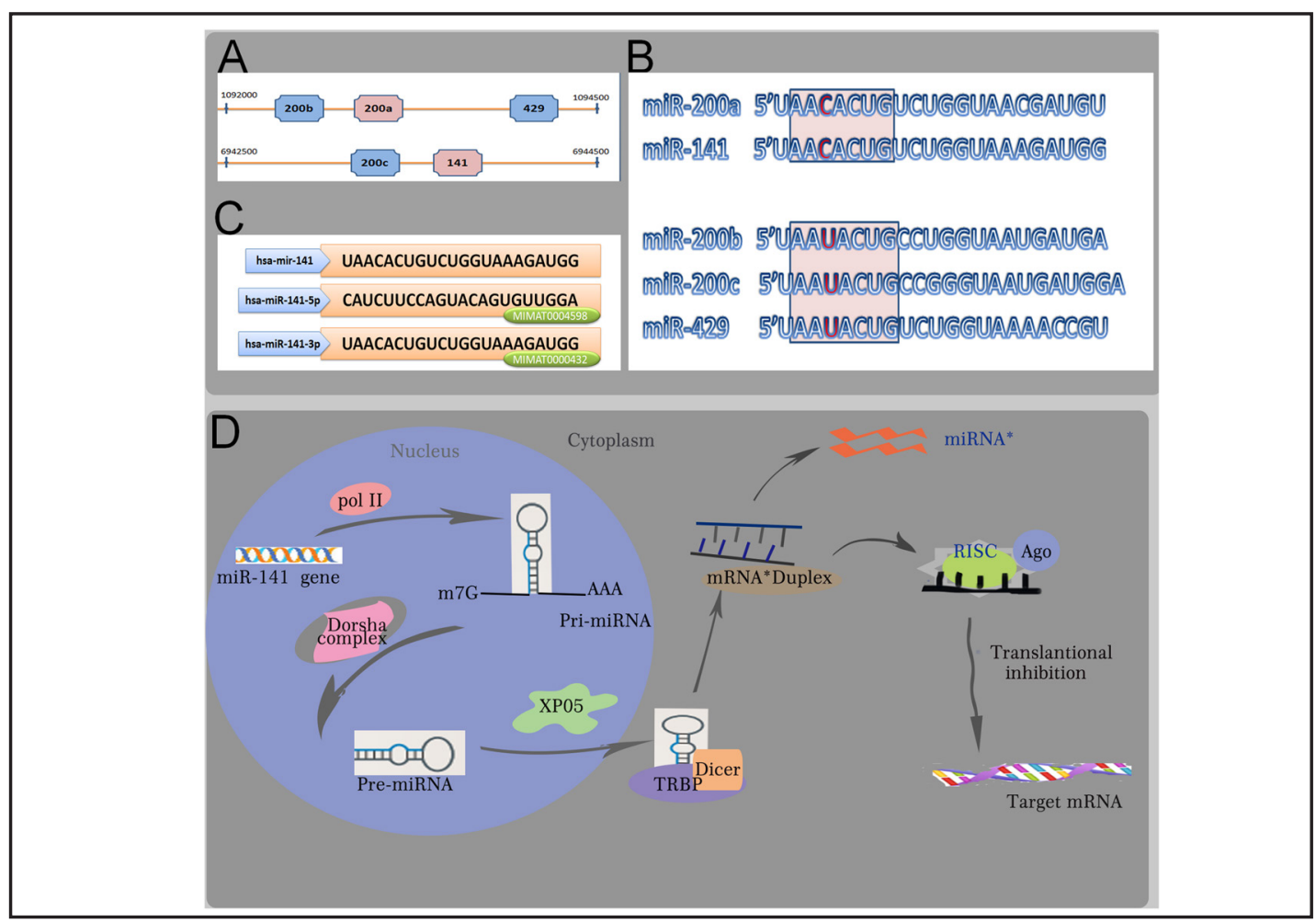

Fig. 1. The miR-141 gene locus in human genome and the processing procedure of a mature miRNA. (A) Features of the miR-200 family members which are located on two different genetic loci. (B) The miR-200 family of miRNAs consists of two closely related subfamilies. It consists of two clusters based on seed sequence similarity and distinguished by a single nucleotide change (U to C). (C) Mature miR-141 has two different forms, namely $5 p$ and $3 p$, according to which side of the strand they are derived from. (D) Model for miR-141 processing: Drosha cuts Pri-miRNA into the stem-loop structural pre-miRNA, and then removes the loop region from pre-miRNA by Dicer, leaving the mature sequence.

RNAi (RNA interference) enzyme complex [27, 28]. The duplex is unwound by helicase and the guide strand is loaded into RISC while the passenger strand is released. However, sequencing results of recent studies suggest that the passenger strand itself may also target gene expression $[29,30]$. The RISC has been reported to down-regulate target genes by translational repression or mRNA cleavage [31, 32]. The specificity of miRNA targeting is defined by how complementary are the "seed" sequence (positions 2 to 8 of the 5' miRNA) and the "seed-match" sequence (generally in the 3' UTR of the target mRNA). A perfect match between miRNAs and mRNA sequences promotes the degradation of mRNAs by Ago1/2, while an imperfect match usually leads to translational repression [33]. So it is not surprising that one single miRNA is capable of binding to hundreds of mRNAs, while a single mRNA may have target sites for multiple miRNAs.

\section{A Dual Role of MiR-141 in Human Cancers}

Based on high-throughput techniques, a great deal of deregulated miRNAs were screened out in various human malignancies and suggested to possess oncogenic or tumor suppressive activities [34]. For instance, miR-141 is overexpressed in ovarian and NSCLC tissues, nasopharyngeal carcinoma, prostate cancer (PCa), classic papillary thyroid carcinoma, bladder cancer and colorectal cancers, while down-regulated in gastric cancer, pancreatic ductal adenocarcinoma, pancreatic cancer, osteosarcoma, prostate cancer, 


\section{Cellular Physiology Cell Physiol Biochem 2016;38:427-448

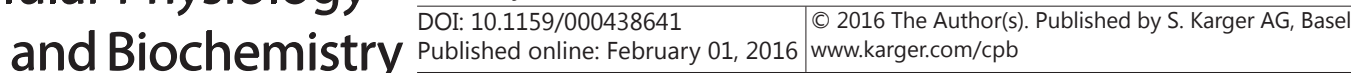 \\ Gao et al.: MiR-141: a Potential Therapeutic Target for Human Cancers}

Table 1. Dysregulation of miR-141 in cancers

\begin{tabular}{llll}
\hline Cancer type & $\begin{array}{l}\text { miR-141 } \\
\text { expression }\end{array}$ & Functional target & \\
\hline PDAC & Downregulation & YAP1 & {$[90]$} \\
$\begin{array}{l}\text { Pancreatic Cancer } \\
\text { Gastric cancer }\end{array}$ & $\begin{array}{l}\text { Downregulation } \\
\text { Downregulation }\end{array}$ & $\begin{array}{l}\text { MAP4K4; MUC1; TM4SF1 } \\
\text { HDGF;AZ; ZEB1/2; STAT4; KEAP1; }\end{array}$ & {$[42,50,87,103]$} \\
$\begin{array}{l}\text { Osteosarcoma } \\
\text { Renal childhood neoplasms }\end{array}$ & Downregulation & $\begin{array}{l}\text { E-cadherin; } \\
\text { ReB1 and ZEB2 }\end{array}$ & {$[44]$} \\
Renal cell carcinoma & Downregulation & ACVR2B & {$[54]$} \\
$\begin{array}{l}\text { Esophageal cancer } \\
\text { Breast cancer }\end{array}$ & Downregulation & CDC25B; EphA2; ZFHX1B; Ago2 & {$[14,55,56]$} \\
& Downregulation & SOmplex & \\
$\begin{array}{l}\text { HCC } \\
\text { Choriocarcinoma }\end{array}$ & Downregulation & p27/Kip1;CDK6; PR and Stat5a & {$[10,51]$} \\
$\begin{array}{l}\text { Ovarian cancer } \\
\text { Bladder cancer }\end{array}$ & Downregulation & Tiam1; ZEB2; DLC-1; HNF-3 $\beta$ & {$[17,43]$} \\
$\begin{array}{l}\text { Prostate cancer } \\
\text { NSCLC }\end{array}$ & Downregulation & & {$[45,101]$} \\
$\begin{array}{l}\text { Nasopharyngeal carcinoma } \\
\text { (NPC) } \\
\text { cPTC } \\
\text { Colorectal cancer }\end{array}$ & Upregulation & P38a; KEAP1 & {$[78]$} \\
\hline
\end{tabular}

hepatocellular, primary peritoneal carcinoma, choriocarcinoma, esophageal cancer, breast cancer and renal cell carcinoma, raising a controversial issue about the role of miR-141 in cancer progression (Table 1). Interestingly, dysregulation of miR-141 is depending on the type of cancers; in other words, miR-141 plays a dual role in tumorigenicity and can modulate cellular motility and control "stemness" [35]. This phenomenon strongly suggests that miR-141 is a core oncogene or tumor suppressor gene and provides new options for the targeting of cancer therapeutic agents.

\section{Upstream and Downstream Pathways of MiR-141}

There is an evolutionarily conserved signal transduction cascade involved in the control of many fundamental cellular processes (Table 2). In this review, we briefly summarize the current knowledge concerning to the regulatory network of miR-141 (Fig. 2-3) and discuss whether this novel regulation mechanism is conductive to get a new breakthrough in different human cancers.

Accumulating evidence shows that both genetic and epigenetic alterations can cause miRNA dysregulation [36]. And promoter hypermethylation is the best studied of the epigenetic changes [37]. It is well known that mammalian DNA is predominantly methylated at the C-5-position of complimentary CpG bp by DNA methyltransferases [38]. DNA methylation of $\mathrm{CpG}$ islands is also present in the promoter region of miRNAs with tumor suppressor features. For instance, anomalous DNA methylation of the miR-200c/miR-141 CpG island is strongly associated with their inappropriate silencing in cancer cells [39]. Furthermore, DNA methylation maintains the balance of tissue-specific expression of the miR-200c/141 cluster in normal cells and affects the phenotypic changes observed in cancer cells. Current findings indicate that downregulation of miR-200c and miR-141 is due to a highly methylated $\mathrm{CpG}$ island located upstream of their genomic sequence and/or upregulated transforming growth factor (TGF)- $\beta$ signaling [40]. The double-negative feedback loop controlling ZEB1 is perhaps the best known mechanism of miR-200c/141 action. ZEB1 and ZEB2 expressions in gastric cancer tissue are higher than the matched adjacent tissues. In breast cancer, it is also indicated that the TGF- $\beta$ /miR-200/ZEB signaling network regulates the establishment and maintenance of EMT [41]. Interestingly, it was reported that the transmembrane glycoprotein 


\section{Cellular Physiology Cell Physiol Biochem 2016;38:427-448

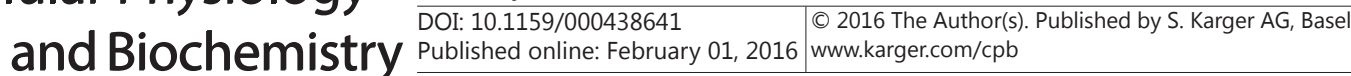

Table 2. The common targets of miR-141

\begin{tabular}{|c|c|c|c|}
\hline $\begin{array}{l}\text { Target } \\
\text { genes }\end{array}$ & Associated cancers & Biological function & Reference \\
\hline $\begin{array}{l}\text { ZEB1 } \\
\text { /ZEB2 }\end{array}$ & $\begin{array}{l}\text { Gastric cancer, Breast cancer, } \\
\text { Osteosarcoma }\end{array}$ & $\begin{array}{l}\text { enhancing the capability of migration and invasion } \\
\text { by inhibiting the expression of E-cadherin; } \\
\text { suppressing both the growth and the motility of } \\
\text { HCC cells; anti-proliferation; pro-apoptosis }\end{array}$ & {$[40,41,44]$} \\
\hline ZEB2 & $\begin{array}{l}\text { HCC, colorectal cancer, } \\
\text { Cholangiocarcinoma, Ovarian cancer, } \\
\text { NSCLC }\end{array}$ & $\begin{array}{l}\text { inhibition of E-cadherin expression and promotion } \\
\text { of tumor progression and metastasis }\end{array}$ & {$[6,69,100,101]$} \\
\hline YAP1 & $\begin{array}{l}\text { Pancreatic cancer, } \mathrm{HCC} \text {, Breast } \\
\text { cancer, Oral squamous cell } \\
\text { carcinomas, Esophageal squamous } \\
\text { cell carcinomas }\end{array}$ & $\begin{array}{l}\text { inhibiting growth and enhancing caspase-3- } \\
\text { dependent apoptosis }\end{array}$ & {$[51,87,90,91]$} \\
\hline HDGF & Gastric cancer & $\begin{array}{l}\text { regulating aggressive biological abilities of tumors } \\
\text { including proliferation and poor prognosis }\end{array}$ & {$[47]$} \\
\hline TAZ & $\begin{array}{l}\text { Gastric cancer, Breast cancer, } \\
\text { Malignant glioma, NSCLC }\end{array}$ & $\begin{array}{l}\text { regulating epithelial-to-mesenchymal transition } \\
\text { (EMT), proliferation, apoptosis, tumor formation } \\
\text { and organ size }\end{array}$ & {$[49,79,80]$} \\
\hline STAT4 & PTC, Gastric cancer & $\begin{array}{l}\text { suppressing cell migration, invasion and } \\
\text { metastasis }\end{array}$ & [48] \\
\hline KEAP1 & Ovarian cancer, Gastric cancer & transcriptional regulator of oxidative stress & {$[16,146]$} \\
\hline SoX17 & Esophageal cancer & $\begin{array}{l}\text { methylated and in a progression tendency during } \\
\text { esophageal carcinogenesis }\end{array}$ & [10] \\
\hline EphA2 & Renal cell carcinoma & inhibiting the migratory and invasive properties & [14] \\
\hline $\mathrm{c}-\mathrm{MYC}$ & Nasopharyngeal carcinoma & transcriptional regulation of its target genes & {$[58,59]$} \\
\hline SPLUNC1 & Nasopharyngeal carcinoma & $\begin{array}{l}\text { innate immunity-defensive secretory protein and } \\
\text { bind to bacterial lipopolysaccharide and inhibit } \\
\text { Pseudomonas aeruginosa and Epstein-Barr virus }\end{array}$ & {$[58,59]$} \\
\hline BRD3 & Nasopharyngeal carcinoma & inhibiting cell growth and inducing cell arrest & {$[58,59]$} \\
\hline UBAP1 & Nasopharyngeal carcinoma & containing two ubiquitin-associated domains & {$[58,59]$} \\
\hline PTEN & Nasopharyngeal carcinoma & negative regulator of AKT signaling pathway & [58] \\
\hline ZFHX1B & Renal cell carcinoma & a transcriptional repressor for CDH1/E-cadherin & [70] \\
\hline p38a & Ovarian cancer & blocking proliferation or promoting apoptosis & [123] \\
\hline SIP1 & $\begin{array}{l}\text { Colon cancer, Ovarian cancer, Breast } \\
\text { cancer, Gastric cancer }\end{array}$ & inhibiting migration and invasion & {$[7,52,70]$} \\
\hline Stat5a & Breast cancer & facilitating breast cancer cell dedifferentiation & [43] \\
\hline
\end{tabular}

MUC1 could regulate miR-200c/141 expression in pancreatic cancer cells by decreasing transcript production at the promoter of miR-200c/141 as well as directly interacting with ZEB1, which is responsible for phosphorylation of the YEKV motif [42].

Given that the number of target genes is still growing, there is a complicated regulatory network for miR-141.And by regulating those target genes, miR-141 exerts a dual role in tumorigenicity.It was demonstrated that P4 down-regulation of miR-141 could facilitate an increase in stem-like breast cancer cells [43]. Inhibition of miR-141 alone potentiated the CD44 high population and strengthened P4-mediated increases in both CD44 high and CK5 ${ }^{+}$cells. MiR-141 directly targeted both PR and Stat5a which is a sore of transcription factor important for MaSC expansion. Loss of miR-141 increased PR protein levels which was estrogen dependent even in cell lines. Furthermore, miR-141 depletion enhanced both mammosphere formation and tumor initiation. The mechanism controlling mammary cell fate by which P4-triggered loss of miR-141 aids in breast cancer cell de-differentiation through dysregulation of PR and Stat5a.

MiR-141 was also reported to play an osteosarcoma-suppressing role via ZEB1 and ZEB2 [44]. Liu et al. revealed that miR-141 could function as a tumor suppressor in HCC cells by targeting Tiam1 [45]. Besides, hepatocyte nuclear factor-3 $\beta$ protein levels were consistently upregulated in HCC clinical tissues compared with matched normal adjacent tissues. High expression of hepatoma-derived growth factor was positively associated with aggressive phenptypes of tumors including proliferation, angiogenesis, and poor prognosis of patients [46]. Chen et al. identified HDGF as a direct target of miR-141 in GC cells [47]. MiR-141 could also act as a tumor suppressor through directly targeting transcriptional co-activator with PDZ-binding motif and subsequent cell proliferation repression as well 
Fig. 2. The upstream regulation and downstream targets of miR-141. By modulating multiple targeting, miR-141 regulates different cellular processes, including proliferation, migration, EMT, chemosensitivity and so on. The details could be obtained in context.

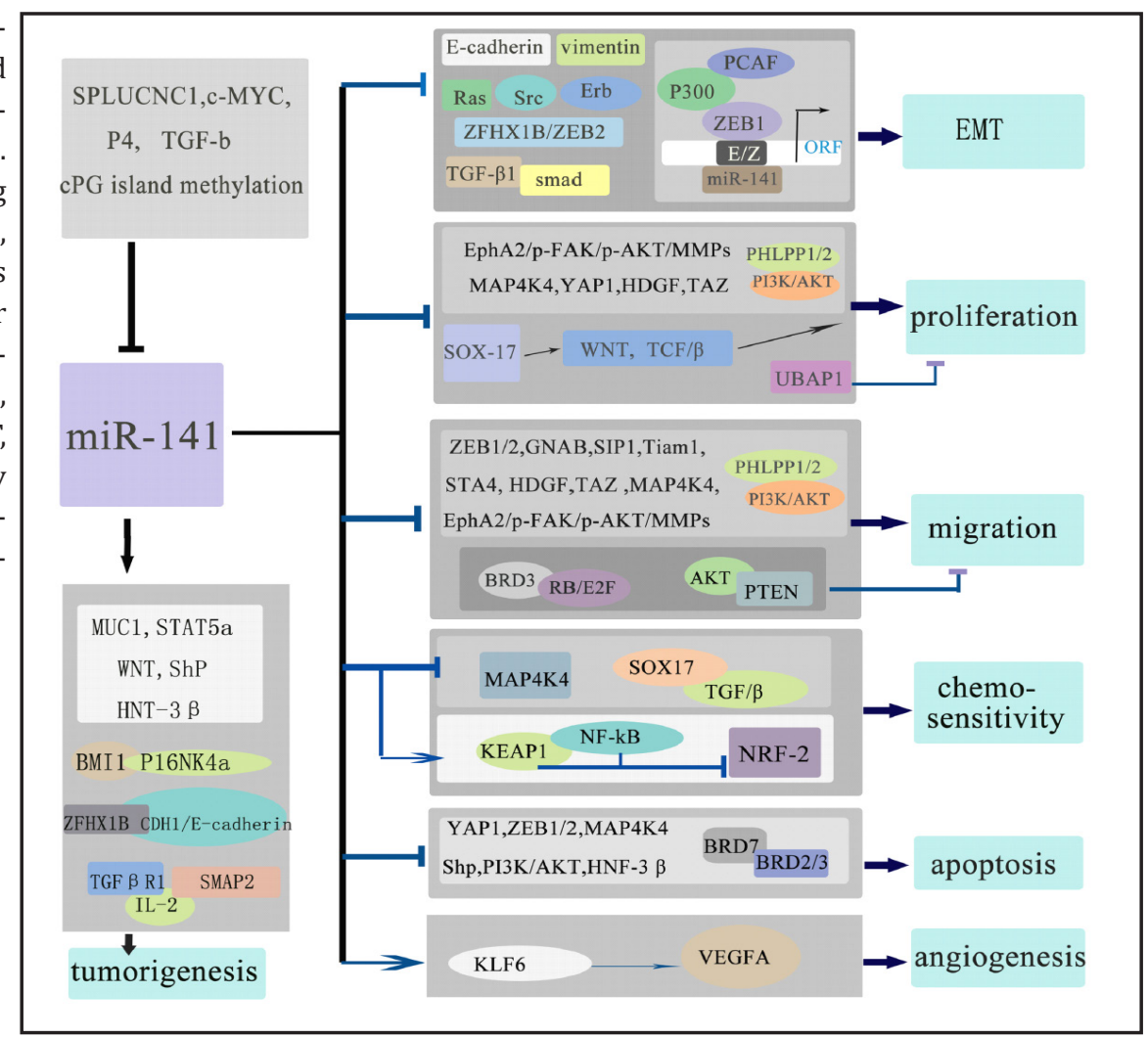

Fig. 3. Other special biological activities regulated by miR-141 involve HCV-related hepatocarcinogenesis, the interaction between IncRNA and miRNA, and tumor-associated oxidative stress response.

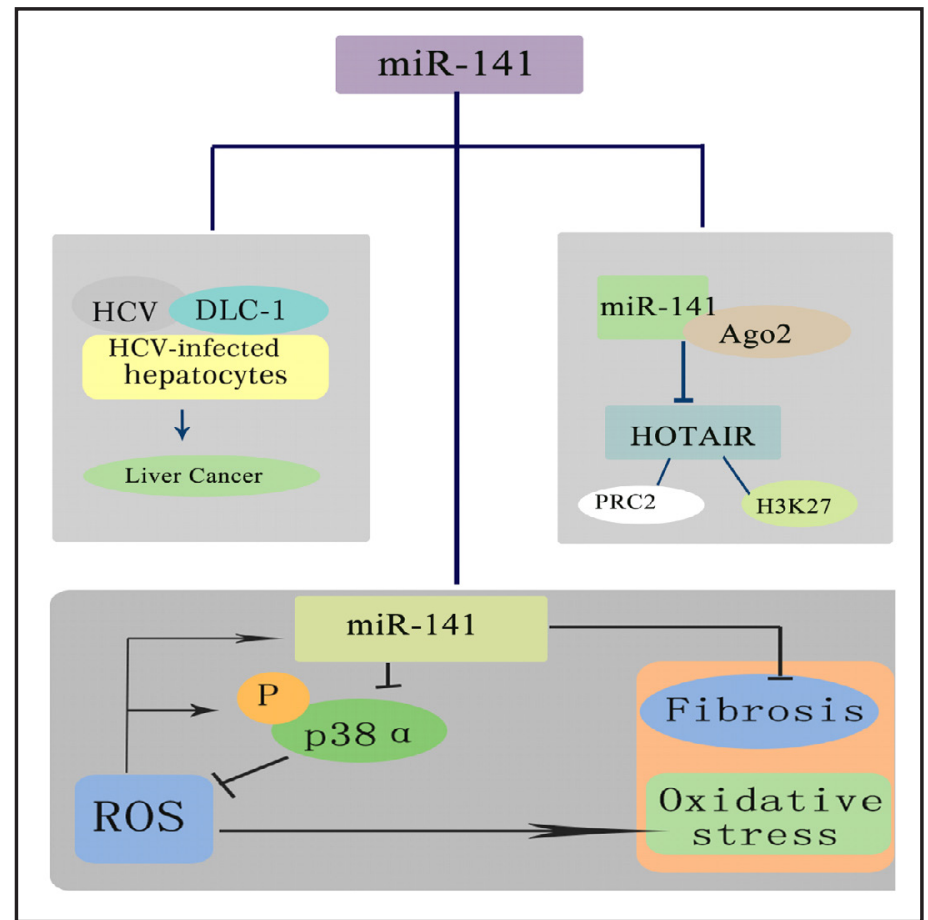

as cell invasion and migration inhibition in GC cells. Recently, kelch-like ECH-associated protein 1 was identified as a direct target of miR-141 in GC. Furthermore, miR-141 inhibited gastric cancer invasion via repression of STAT4. Therefore, the miR-141-STAT4 pathway may be exploited in a therapeutic approach for the treatment of $\mathrm{H}$. Pylori related cancers [48]. Functional researches suggested that miR-141 could not only inhibit growth and KARGER 
colony formation but also enhance caspase-3-dependent apoptosis in pancreatic ductal adenocarcinomacells by targeting Yes-associated protein-1 [49]. In pancreatic cancer, another research demonstrated that miR-141 could directly bind to $3^{\prime}$-UTR of mitogenactivated protein kinase isoform 4 to inhibit MAP4K4 expression and lead to the inhibition of cell proliferation [50]. In esophageal cancer, inhibition of SRY-box containing gene 17 (SOX17) by miR-141 or by methylation both activated the WNT-signaling pathway and promoted esophageal tumorigenesis. Upon SOX17 restoration, TGF/ $\beta$-catenin-dependent transcription and colony formation could be suppressed. MiR-141 was also expounded to induce cisplatin resistance through downregulation of YAP1 in human esophageal carcinoma [51]. In addition, Hu et al. reported that miR-141 could regulate Smad interacting protein 1 and inhibit migration and invasion of colorectal cancer cells [52]. Poell et al. also reported that miR-141 could inhibit the proliferation of melanoma cells [53]. And, Senanayake et al. found that miR-141 was down-regulated in renal childhood neoplasms, and targeted the activin receptor type $2 \mathrm{~B}$, which was a member of the TGF- $\beta$ pathway [54]. Yu et al. showed that miR-141 was downregulated in human renal cell carcinoma and regulated cell survival by targeting CDC25B [55]. The transcriptional loss of miR-141 resulted in increased CDC25B expression which could increase genomic instability at an early stage of renal cell carcinoma development. Chen et al. also found that miR-141 was decreased in renal cell carcinoma via targeting erythropoietin-producing hepatocellular (Eph) A2 [14]. Functional enrichment analysis helped to elucidate that down-regulation of miR-141 and miR-200c in renal cell carcinoma are both involved in depression of CDH1/E-cadherin transcription via upregulation of ZFHX1B [56].

Interestingly, dysregulation of miR-141 rests with the type of cancers; in other words, miR-141 plays a two-tier role in tumorigenicity sequentially modulate cellular motility. MiR141 has been found to be upregulated in some cancers and act as an onco-miRNA. Zhang et al. suggested that the expression level of miR-141 was elevated in the serum of patients with bone-metastatic prostate cancer and positively correlated with more bone lesions [57]. Zhang et al. reported that miR-141 was up-regulated in NPC specimens in comparison with normal nasopharyngeal epithelium [58]. Either knockdown of oncogene c-MYC or re-expression of tumor suppressor gene SPLUNC1 exerted remarkable influences on the miRNA profiles in NPC. This discovery simultaneously identified BRD3, UBAP1 and PTEN as direct targets of miR-141. MiR-141 showed an inverse correlation to the protein expression of G-protein subunit a-13 in prostate cancer cells, and forced overexpression of miR-141 negatively regulated the invasion capability of prostate cancer cells [59]. Interestingly, Xiao et al. have found that Small heterodimer partner was a target of miR-141 and was downregulated in cultured human PCa cells with the involvement of upregulation of miR141, which accelerated AR transcriptional activity [60]. Current research appears to validate such a view that miR-141 posttranscriptionally drops off BMI1 expression in human diploid fibroblasts by means of a miR-141 targeting sequence in the 3 '-untranslated region of BMI1 mRNA [61]. To our surprise, miR-141 expression was actually up-regulated in NSCLC tissues [62]. It was subsequently reported that PH domain leucine-PHLPP1 and PHLPP2 as target genes of miR-141 were antagonists of PI3K/AKT signaling by firsthand dephosphorylating AKT, which played crucial roles in cell proliferation, survival, differentiation and migration [63, 64]. Most reported studies supported that the LIF-induced STAT3 activation in trophoblastic cells seemed to be vital for a series of cell functions. It's observed that Hashimoto thyroiditis epithelium could be distinguished from neoplastic follicular thyroid epithelium isolated from classic papillary thyroid carcinoma and control epithelium based on the relative expression of miR-141.

\section{The Functions and Pathways Involving MiR-141 Targets}

Considering the cancer type-depending dysregulation of miR-141, it is not surprising that miR-141 could play a dual role in tumorigenicity, functioning either as a tumor suppressor or promoter. 


\section{MiR-141 and EMT}

As is well-known, EMT is a facilitator of tissue remodeling in many physiological progressions such as embryonic development, wound healing, tissue regeneration and organ fibrosis [65]. EMT is also a fatal early step in tumor metastasis formation by controlling the detachment of invasive cancer cells from the primary tumor [66]. During EMT, the phenotypical changes and the gain of invasive capacity are consequences of a cascade of events ultimately leading to the attenuation of cell-to-cell adhesion proteins, such as downregulation of E-cadherin and up-regulation of Vimentin [67]. Owing to their expressing proteases that allow them to pass through the underlying basement membrane and migrate, the cells become more invasive to start the multistep process of metastasis, or escape from apoptosis and senescence as wll as immunosuppression [68]. An ocean of growth factors, including TGF- $\beta$ and its downstream effectors Ras and Src, are involved in EMT. During the past years, much work has been done to investigate the function of the miR-200 family in EMT of cancers. Data from renal cell carcinoma showed that the ErB signaling pathway was significantly regulated by miR-141, which played a significant role in the process of EMT [68]. Another study demonstrated that the miR-200 family, especially miR-141 and miR$200 \mathrm{a}$, held the ability of suppressing TGF- $\beta 1$-induced renal tubular EMT through Smad pathway by targeting ZEB1 and ZEB2 [69]. As mentioned above, ZFHX1B/ZEB2 is a molecular target of miR-200 family members. ZFHX1B, also known as SIP1 and ZEB2, functions as a transcriptional repressor for $\mathrm{CDH} 1 / \mathrm{E}$-cadherin, and enforced over-expression of ZFHX1B induces Vimentin [70].

Previous studies exhibited that forced expression of SPRR2a was a powerful inducer of EMT. Mizuguchi et al. depicted the role of acetyltransferases on the miRNA-200c/141 promoter and their effect on the epithelial/mesenchymal status of the cells [71]. They described that the deacetylase inhibitor TSA as well as P300 and PCAF can lead to a shift towards epithelial characteristics in HUCCT-1-SPRR2a cells. P300 belongs to the KAT3 histone acetyltransferases which has at least 400 interacting protein partners and P300 is also thought to be an anti-cancer gene as the potential of P300 to restrain cancer progression is linked to phenotypes including EMT $[72,73]$. Both P300 and PCAF could act as cofactors of ZEB1 and form a P300/PCAF/ZEB1 complex on the miR200c/141 promoter. This special binding results in lysine acetylation of ZEB1 and a release of ZEB1 suppression on miR200c/141 transcription. Next disruption of P300 and PCAF interactions dramatically down regulates miR-200c/141 promoter activity, indicating a PCAF/P300 cooperative function in regulating the transcriptional suppressor/activator role of ZEB1. EMT seems to be the early stage of metastasis, but later, following extravasation, metastasizing cells settle in target tissue and undergo differentiation processes that relate MET [74]. MET processes are controlled by a network of transcriptional regulators and can be affected by posttranscriptional and posttranslational modifications. Another research suggested that during EMT, miR-141 expression was repressed in a dose- and time-dependent manner through upregulation of HIPK2 expression. Though reducing E-cadherin, HIPK2 gained aberrant expression to promote EMT. Then, co-transfection of miR-141 with the HIPK2 ORF clone partially inhibited EMT by restoring E-cadherin expression. These novel findings contribute to obtain the understanding of the role of miR-141 in regulating renal fibrosis via the TGF- $\beta 1 / \mathrm{miR}$ 141/HIPK2/EMT axis, where miR-141 down-regulates the expression of HIPK2 via direct interaction with the 3'-UTR of HIPK2. Taken together, in-depth understanding about the mechanisms of miR-200 family affecting cancer cell phenotypes, can be conducive to yield clarification of tumor progression as well as latent therapeutic targets.

\section{MiR-141 and Cell Proliferation}

Uncontrolled cell proliferation is the most significant characteristic of cancer cells. How fast a tumor grows helps to show how aggressive the tumor is and how likely it is to spread to other parts of the body. In addition, proliferation rate is also an important predictor of therapeutic sensitivity.

\section{KARGER}


The miR-200 family has been demonstrated to be overexpressed in PDAC cells with effect on cell proliferation enhancement [75]. Analogical results have been found in cholangiocarcinoma, ovarian carcinoma and choriocarcinoma [76-78]. However, overexpression of miR-141 was reported to significantly inhibit the proliferation of GC. Growth inhibitory effects of miR-141 are in part mediated through its downstream target gene TAZ. TAZ is a transcription cofactor also known by gene name WW domain-containing transcription regulator 1 , which plays pivotal roles in EMT, cell growth and organ development $[79,80]$. TAZ was recently proposed to endow self-renewal capacity to cancer stem cells and inversely correlated with miR-141 levels in the primary GC tissues. Therefore, it was concluded that the upregulation of TAZ induced by suppression of miR-141 contributed to tumor progression in GC. A previous study suggested that overexpression of miR-141 suppressed HCC cell growth and invasion via ZEB2 targeting. Moreover, miR-141 inhibited proliferation of osteosarcoma cell lines, so overexpression of ZEB2 could more significantly inhibit the osteosarcoma cells proliferation [44]. And as mentioned, miR-141 participants in a complex NPC-related oncogenes-tumor suppressor genes network contributing to NPC tumorigenesis where miR-141 inhibition can regulate the Rb/E2F pathway that is critical for normal cell cycle progression from G1 into S phase. Inactivating RB and E2F/DP transcription factors lead to transcription of a number of genes essential for DNA replication and entrance into S phase though exerting their transactivation activity [81]. BRD3, PTEN and UBAP1 have been demonstrated to act as direct targets of miR-141. BRD3 and UBAP1 are both involved in NPC carcinogenesis as confirmed through their previous studies and PTEN is a crucial tumor depressor in numerous tumor types. BRD3 is a potential nuclear transcription factor and belongs to a bromodomain family which negatively regulates $\mathrm{Rb} / \mathrm{E} 2 \mathrm{~F}$ pathway [82]. Phosphorylation of AKT is negatively regulated by PTEN, which plays an particular role in the activation of cascade of different protein targets involved in cell growth, proliferation and invasion, and promote tumorigenesis [83]. MiR-141 helps to inhibit PTEN expression via increasing the AKT phosphorylation levels. Rb/E2F, JNK2 and AKT pathways have been underlying affected by inhibition of miR-141. This gene-miRNA network involves miR-141 and tumor-related genes c-MYC, SPLUNC1, BRD3, UBAP1 and PTEN, which may contribute to NPC development. Several bioinformatical tools suggested that UBAP1 protein was involved in conferring target specificity to multiple enzymes of the ubiquitination system. The ubiquitin-dependent pathway plays a decisive role in understanding the pathological states including abnormal cellular proliferation and tumor growth. The foregoing result that the expression levels of miR-141 in NSCLC were overtoped than those in normal tissues was amazing [84]. Mei et al. discovered that miR-141 expression was markedly up-regulated in NSCLC tissues, and its overexpression promoted NSCLC cell proliferation in vitro and tumor growth in vivo [62]. The molecular mechanisms by which miR-141 accelerated cell proliferation were further investigated. The antagonists of PI3K/AKT signaling, PHLPP1 and PHLPP2, are targets of miR-141. Re-introduction of PHLPP1 and PHLPP2 abrogated miR141-induced proliferation of NSCLC cells. In line with the results, Leukemia inhibitory factor significantly downregulated miR-141. LIF is well known to induce tyrosine phosphorylation of signal transducer and activator of transcription 3 in a variety of trophoblast and choriocarcinoma cell lines where it induces invasiveness [85, 86]. Silencing of miR-141 inhibits proliferation of JEG-3 choriocarcinoma cells, while over-expression does not further induce proliferation.

Several miRNAs have been elucidated to regulate cell proliferation by targeting key intermediates in cell cycle progression. Among them, expression of the miR-200a/141 cluster results in G1 arrest attributed to aggrandized p27/Kip1 expression and reduced cyclindependent kinase 6 expression. However, expression of the 200bc/429 cluster decreases G1 population and induces G2/M phase arrest, in line with reduction of p27/Kip1 and upregulation of the inhibitory phosphorylation of Cdc25C, respectively. In pancreatic cancer cells, up-regulating miR-141 by targeting MAP4K4, inhibited cell proliferation, clonogenicity, and induced G1 arrest [87]. MAP4K4 belongs to the mammalian STE20/MAP4K family, which is associated with cell motility, rearrangement of the cytoskeleton, and cell growth

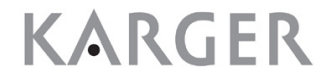


[88]. Moreover, miR-141 could promote G1/S phase transition of NSCLC cells in vitro and tumor growth in vivo, comfirming the oncogenic role of miR-141.

\section{MiR-141 and Apoptosis}

Apoptosis is recognized as the process of programmed cell death that may occur in multicellular organisms. In living organisms, apoptosis can cause disastrous effects, often in the form of disease, disorder or cancer. Therefore, the balance of anti-apoptotic and proapoptotic effectors in favor of deciding the damaged cells continue to replicate or to die. As a consequence, blocking of apoptosis in cells that are gaining oncogenic mutations can lead to tumor progression.

Several studies have shown that the miR-8-null fly, which was the Drosophila homolog of human miR-200 family, revealed increased apoptosis in the brain and smaller body size compared with wild types [89]. More importantly, overexpression of YAP1 could rescue not only the downregulation of YAP1 but also the growth inhibition and caspase-3-dependent apoptosis enhancement in PANC-1 cells induced by miR-141 upregulation [90]. YAP1 was first identified by virtue of its ability to associate with the SH3 domain of Yes-and Srcprotein-tyrosine kinases [91]. The assays demonstrated that the expression of miR-141 was inversely correlated with YAP1 protein in PDAC tissues. Overexpression of miR-141 could not only inhibit osteosarcoma cell proliferation but also induce cell apoptosis via ZEB1 and ZEB2 targeting [44]. In NPC, BRD2 and BRD3 interacted with BRD7 and played distinct roles in regulating cell apoptosis. In pancreatic cancer cells, miR-141 targeted MAP4K4, acting as a tumor suppressor which helped to induce apoptosis [87]. Some researchers demonstrated a significant increase in Shp expression and a marked reduce of miR-141 (both mature miR141 and pri-miR-141) after PEITC treatment in LNCaP cells. Shp is an atypical member of the steroid/thyroid hormone nuclear receptor family of transcription factors and identified as an vital transcriptional co-repressor and metabolic regulator [92]. PEITC is a natural component of the organic isothiocyanates existing in the cruciferous vegetables and displays anti-proliferative effects on PCa and preneoplastic cells. Ulteriorly, PEITC could inhibit AR transcriptional activity in PCa cells, manifesting in respects containing inhibition of cytochrome P450 enzymes, reactivation of oxygen species production, and induction of apoptotic cell death [93-95]. MiR-141 is also involved in the PI3K/AKT signaling, where AKT plays a crucial role in holding the balance between proliferation and quiescence, as well as cell survival and apoptosis [96]. The downregulation of miR-141 can promote apoptosis in HepG 2 cells during HCC carcinogenesis, at least partially, by modulation of HNF-3 $\beta$ [97].

\section{MiR-141 and Tumor Invasion and Metastasis}

It is theorized that metastasis always coincides with a primary cancer, and, as such, is a tumor that started from a cancer cell or cells in another part of the body. However, over $10 \%$ of patients presenting to oncology units will have metastases with no primary tumor detected. Treatment and prognosis are determined, to a great extent, by whether the tumor remains localized or not. Malignancies allow for invasion into the circulation, followed by invasion to a second site for tumorigenesis. Several studies have exploited potential strategies that can prevent or at least slow down the spread of cancer by somehow blocking the two steps [98]. Metastasis is a complex process and the leading cause of cancer-related deaths. Reinforcing the understanding of the underlying mechanisms could be conducive to facilitating the development of effective metastasis-targeted therapies and improving the overall prognosis.

It was reported that the expression of miR-141 was significantly correlated with a more aggressive phenotype in clinic [49]. That is to say, miR-141 suppressed in vitro migration and invasion of GC cells. HDGF, which encoded high mobility group protein 1-like 2 protein, was identified as a target of miR-141 in GC cells [47]. HDGF expression gradually increased in the GC carcinogenesis process and had a higher level in poorly differentiated adenocarcinoma cells prone to lymphoid metastasis. HDGF overexpression significantly activated Erk1/2 in gastric epithelial cells and promoted anchorage-independent growth 
[99], partially attenuating the suppressive effect of miR-141. Moreover, the negative correlation between miR-141 and its target was verified in patients and xenograft mice. Overexpression of miR-141 suppressed tumor growth and pulmonary metastasis in nude mice. In clinical samples, the expression of miR-141 was inversely correlated with TNM stage, tumor invasion depth, tumor embolus and disease-free survival [40]. Further study indicated that the miR-200c and miR-141 cluster (miR-200c/141) could inhibit migration and invasion of gastric cancer by directly targeting of ZEB1 and ZEB2 and the subsequent restoration of E-cadherin [100]. Others also found that miR-141 was decreased in renal cell carcinoma, inhibiting the migratory and invasive properties by ZEB2 suppression [101]. In addition, miR-141 played a pivotal role in getting command of gastric cancer invasion through regulating signal transducer and activator of transcription 4, which was a critical accelerator of gastric cancer metastasis and widely up-regulated in many carcinomas [102]. MiR-141 acted as an oncogene to influence NPC cell cycle, migration and invasion by positive regulation of $\mathrm{Rb} / \mathrm{E} 2 \mathrm{~F}$ and $\mathrm{AKT}$ pathways. Current findings indicated that methylation of the miR-200c/141 promoter led to shutdown of promoter activity, while treatment with demethylating agents caused transcriptional reactivation of miR-200c and miR-141 in breast cancer cells. In addition, DNA methylation of miR-200c/141 promoter was closely correlated with the invasive capacity of cancer cells [67]. In breast cancer, all the members of miR-200 family were involved in EGF-driven invasion, and the miR-200bc/429 cluster showed stronger effects than the miR-200a/141 cluster. MiR-141 was down-regulated in HCC tissues, functioning as a tumor suppressor by inhibition of the migration and invasion of HCC cells via direct targeting of the metastasis-related gene Tiam1 [103]. Tiam1 is a member of the Dbl family of guanine nucleotide exchange factor that can affect small G proteins of the Rho family. MiR-141 inhibited HNF-3 $\beta$ expression, subsequently inhibiting cell invasion in HepG2 cells. HNF-3 $\beta$ belongs to the HNF-3/forkhead family of transcription factors in mammals and plays important roles in hepatocyte differentiation and HCC development. Studies have suggested miR-141 as a potential link between the HNF-3 $\beta$ regulatory pathway and HCC and highlighted the importance of miR-141 as a tumor suppressor in HCC via suppression of HNF-3 $\beta$ translation [97]. It was demonstrated that miR-141 downregulated TM4SF1 expression and inhibit the metastatic potential of PC cells with no effect on cell proliferation, cell cycle progression or apoptosis [103]. As a member of the tetraspanin superfamily, TM4SF1 is a tumor-specific antigen unduly expressed in most of human cancers including lung, breast, colon, ovarian, renal, pancreatic and prostate carcinomas, and weakly expressed in normal vascular endothelium [104].

As a novel biomarker for PCa, plasma miR-141 level can be used to screen for metastatic PCa with high sensitivity [105]. Skeleton is the most common metastatic organ in patients with PCa. It was reported that serum miR-141 levels were increased in patients with bonemetastatic PCa and that patients with higher levels of miR-141 suffered more bone lesions. In addition, serum miR-141 levels were correlated to serum ALP levels but not serum PSA levels. It is illustrated that miR-141 and miR-375 are induced and increasingly released into incubation medium from androgen-stimulated LNCaP cells. Chondrosarcoma is one of malignant bone tumors and has a tendency of local invasion and distant metastasis [106]. A traditional Chinese remedy named Paeonol (2'-hydroxy-4'-methoxyacetophenone) was proved to be capable of inhibiting chondrosarcoma cell migration and invasion though upregulation of miR-141 via PKC and c-Src pathways [107].

MiR-141 and Angiogenesis

All blood vessels are lined by the vascular endothelium, and endothelial cells are key regulators of different aspects of vascular biology including the formation of new blood vessels (angiogenesis) [108]. Dysregulation of the vasculogenesis and angiogenesis pathological processes contributes to development of many diseases, including diverse as cancer, macular degeneration, psoriasis, diabetic retinopathy, thrombosis, and inflammatory disorders including arthritis and atherosclerosis[108]. Angiogenesis is controlled by physical interactions between cells and extracellular matrix as well as soluble angiogenic 
factors, such as vascular endothelial growth factor (VEGF), platelet-derived growth factor (PDGF), and fibroblast growth factor (FGF) families, bind to membrane-bound receptors and transmit signals through kinase-dependent signaling cascades $[109,110]$.

Recent studies have illustrated that a novel potential mechanism of endothelial cells regulation may be through the use of miRNAs. With regard to the anterior research, Mateescu et al. have issued that miR-141 overexpression was related to higher blood vessel formation in ovarian tumors of mouse models [77]. The vascular network is required for the expansion of tumor masses, as inhibition of new vessel formation prevents tumor growth. In addition, Tejero et al. examined the potential impact of the angiogenesis mechanism on the prognostic role of miR-141 in NSCLC [111]. The in vitro angiogenesis role of miR-141 was related to reduction of KLF6 protein levels, increasing the secretion of VEGFA. What's more, they observed that tumors with high levels of miR-141 had a higher number of blood vessels. It has been revealed that overexpression of miR-141 would lead to overproduction of VEGF-A and increased neoangiogenesis in NSCLC [112].

\section{MiR-141 and Tumor-Associated Virus}

Hepatitis $\mathrm{C}$ virus (HCV) infection is prevalently considered a major cause of chronic liver disease and HCC. Accumulating evidence has indicated a direct role of miR-141 in the induction of HCV (1a, 1b, and 2a) - infected primary human hepatocytes by DLC-1 targeting. Identified as a candidate tumor suppressor gene by encoding a Rho GTPase-activating protein, DLC-1 gene was located in chromosome 8p21.3-22 [113], which was frequently deleted in solid tumors including HCC. The GTPase activity of DLC-1 was specific for RhoA, a member of the Ras family of oncogenes [114]. It was reported that effective HCV replication was correlated with miR-141-mediated suppression of DLC-1 [115], suggesting tumor suppressor genes can influence oncogenic virus replication by negatively regulating prooncogenic signaling proteins. HCV replication can be inhibited after depletion of miR-141 with oligonucleotides, whereas accelerated by artificial elevation of intracellular miR-141. The enhanced cell proliferation in HCV-infected hepatocytes can be countered by depletion of DLC-1 via miR-141 introduction. This novel mechanism of HCV infection-associated miRNAmediated regulation of a tumor suppressor protein has offered us with new strategies to intervene in cell proliferation of HCV infection-mediated liver cancer.

\section{MiR-141 and Long Non-Coding RNAs}

Long non-coding RNAs (lncRNAs) has been shown that it acts a role in the recruitment of chromatin modifying complexes and can influence gene expression .However, lncRNAs are not translated into proteins and were primitively deemed to be part of the 'dark matter' of the genome [116]. Recently, emerging evidence shows that lncRNAs are involved in almost all sorts of disease states including oncogenesis. It was recently reported that lncRNA HOTAIR could interact with the polycomb repressive complex and suppress its target genes to accelerate malignancy [117]. HOTAIR is located in the HOXC gene cluster and capable of enhancing H3K27 trimethylation to decrease expression of multiple genes as well as interacting with PRC2 (polycomb repressive complex 2) [118]. HOTAIR expression has closed correlation with cancer cell invasiveness, cell proliferation, cell cycle progression, and escape from apoptosis [119]. Furthermore, an inverse correlation between HOTAIR and miR-141 expressions was implied in renal carcinoma cells. Chiyomaru et al. suggested that miR-141 could suppress HOTAIR expression in an immunoprecipitated Ago 2 -de-pendent manner and restrain HOTAIR functions in cell proliferation and invasion [117]. Also, it was reported that the interaction between miR-141 and lncRNA-H19 in regulating cell proliferation and migration in gastric cancer [120]. These results suggest that the interaction between IncRNA and miRNA will provide a novel element of control in gene regulation.

MiR-141 and Tumor-Associated Oxidative Stress Responses

Current findings indicate that redox regulation has an indispensable role in malignancies. Accumulation of reactive oxygen species (ROS) in tumor cells could damage the cellular KARGER 
components and alter gene expression and cell proliferation [121-123]. Hui et al. 2007 and Kim et al. 2010 reported that miR-141 and miR-200a could modulate the oxidative stress response and stimulate tumor growth in mouse models through direct targeting of p38a, which restrained tumorigenesis by blocking proliferation and promoting apoptosis $[124,125]$. Interestingly, a resensitization effect towards paclitaxel, a ROS-producing therapeutic agent, was also observed upon miR-141 and miR-200a introduction, suggesting the potential of oxidative stress signature as a predictive and prognostic parameter. In ovarian tumor, the miR-200s were shown to be highly expressed in localized tumor and downregulated in metastases, defining a two-stage model of miR-200 expression $[126,127]$. In conclusion, the interaction between miR-141 and cancer-associated oxidative stress response may afford new insight into overcoming resistance of antioxidant supplementation in clinic cases.

\section{MiR-141 in Cancer Diagnosis and Prognosis}

To improve the diagnosis and prognosis accuracy of different cancer entities, ongoing efforts have been made in identifying new biomarkers. Emerging evidence suggested that specific miRNA profiles were capable of distinguishing malignant and non-malignant tissues [128], raising the feasibility of miRNAs in early detection of cancer, prognosis informing, and treatment response monitoring. It was reported that the expression level of miR-141 in PDAC tissues was significantly lower than that in corresponding nontumorous tissues [90]. Downregulation of miR-141 correlated with poorer pT and pN status, advanced clinical stage, lymphatic invasion, and shorter overall survival, suggesting that miR-141 was an independent prognostic factor for PDAC patients. Further study indicated that miR141 functioned as a tumor suppressor gene in PDAC by direct targeting of YAP1. Similar prognostic roles of miR-141 were also detected in pancreatic cancer [87]. In bladder cancer, overexpression of miR-141 occurred more frequently in the bladder cancer tissues with high tumor stage and tumor grade (WHO 2004) and low invasiveness. Wszolek et al. suggested miR-141 upregulation as an independent indicator for favorable prognosis of bladder cancer [129]. In a previous study, miR-141 expression level was proved to be negatively associated with the gastric cancer marker CA724, which was also a valuable prognostic factor. Another study revealed the close correlation between elevation of plasma miR-141 and stage IV colon cancer in a cohort of 102 plasma samples. Moreover, miR-141 expression differed not only in tumor tissues between Stage IV and Stage I-II colon cancer patients but also in tumor tissues and adjacent non-tumor tissues of Stage IV patients. In addition, the combination of miR-141 and carcinoembryonic antigen, a widely used marker for colorectal cancer, helped to boost the detection accuracy of distant metastasis in colon cancer [130]. Interestingly, a high level of miR-141 expression was demonstrated to be associated with both benign and poor prognosis in ovarian cancer [131].

Growth of early stage PCa is androgen-dependent [132]. The serum prostate-specific antigen test along with digital rectal examination have been widely used in detection of early stage PCa. Serum PSA test is also used to monitor PCa recurrence after a set of therapies [133]. Agaoglu et al. 2011, reported that circulating miR-21, miR-141 and miR-221 could help to distinguish PCa patients with metastasis from those with local advanced disease [134]. Among the three miRNAs, miR-141 was the most powerful discriminator of metastatic PCa, indicating the potential of miR-141 as a supplement to PSA testing in clinical application. Distinct from the previous result, no significant difference in miR-141 expression was observed between the patient group and healthy controls. Recent studies revealed that PEITC could inhibit AR transcriptional activation through downregulation of miR-141 and upregulation of Shp in PCa cells, suppressing PCa growth both in vitro and in vivo and reducing the risk of tumorigenesis in animal models [135-137]. MiR-141 downregulation could also attenuate dihydrotestosterone-induced transcription of PSA gene. Besides, circulating miR141 was identified as a novel diagnostic and prognostic biomarker across several other independent studies [138-140]. Interestingly, miR-141 functioned in an androgen dosedependent manner in AR positive cell lines [141].

A specific miRNA expression signature including miR141 was previously reported to

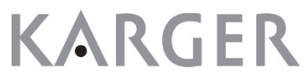


be helpful in differentiating papillary thyroid cancer cell lines from the control thyroid cell line [142]. Further investigation of miR141 regulatory networks contributed to elucidate the molecular mechanisms involved in the fundamental physiological differences among the malignant thyroid phenotypes such as classic PTC, follicular variant PTC, follicular thyroid carcinoma and Hashimoto thyroiditis. HT samples displayed noticeable downregulation of miR141 in comparison with cPTC and control thyrocytes. The downregulation of miR141 was due to its involvement in TGF- $\beta$ pathway, which played important roles in T-cell autoimmunity and had close association with HT through cytokine interleukin-2 regulation. Moreover, a subset of TGF- $\beta$ pathway members were demonstrated to be direct targets of miR-141, such as TGF- $\beta$ R1 and SMAD family member 2 , which were upstream regulatory factors of IL-2 [143].

MiR-141 can also be a potential biomarker for the molecular diagnosis and risk stratification in NSCLC. MiR-141 was reported to be upregulated in NSCLC tissues compared with the corresponding normal ones by several independent studies [62, 84, 144]. This excessive expression of miR-141 was further proved to be associated with the larger tumor size, lymph node metastasis and advanced stage in NSCLC patients. Interestingly, the correlation of miR-141 upregulation and shorter overall survival was only detected in adenocarcinoma, but not squamous cell carcinoma.

\section{MiR-141 in Cancer Treatment}

Resistance to anticancer agents remains a major obstacle to successful treatment of cancer in clinic, and the mechanisms have been extensively investigated at both levels of genes and proteins [145]. Recent reports indicate that miR-141 expression level is correlated with the response of cancer patients to both chemotherapy and molecular-targeted therapy. Cisplatin is the most commonly used anti-tumor chemotherapy agent. Mechanisms of cisplatin resistance include increasing inactivation of cisplatin compounds by glutathione, decreasing accumulation in cells, inactivation of apoptosis pathways and alterations in the repair of DNA lesions. Imanaka et al. 2011, showed that miR-141 could confer resistance to cisplatininduced apoptosis by targeting YAP1 in human esophageal squamous cell carcinoma [51]. In esophageal cancer cell lines, both miRNA-141 targeting and promoter hypermethylation could inhibit SOX17 functions and promote tumorigenesis through wnt-signaling activation [10]. Interestingly, H. pylori infection was reported to significantly down-regulate miR141 expression and ulteriorly modulate cisplatin sensitivity through miR-141-mediated regulation of KEAP1 [146]. KEAP-1 overexpression could transcriptionally inactivate NRF-2, thus playing key roles in transcriptional regulation of oxidative stress which may protect cancer cells from chemotherapeutic agents and facilitate cancer progression [147]. Moreover, overexpression of miR-141 activated NF- $\mathrm{KB}$ signaling pathway through KEAP1 suppression, while that inhibition of this pathway partially reverses miR-141-mediated cisplatin resistance [16]. Notably, miR-141 levels appeared to be higher in resistant than in sensitive non-serous ovarian tumors, proposing that the relationship between miR-141 and therapy response may be histological-dependent. By targeting MAP4K4, miR-141 could partially enhance the chemosensitivity of PANC-1 and MiaPaCa-2 pancreatic cancer cells to 5 -FU and gemcitabine. Treatment with the DNA methyltransferase inhibitor (decitabine) could ameliorate miR-200c/141 downewgulation induced by TGF- $\beta$ in SGC-7901 gastric cancer cells. Besides, miR-141 was also capable of regulating target genes such as p38a, YAP1 etc., highlighting the role of miR-141 as a core factor in the response to chemotherapeutics. As for targeted therapy, Berkers et al. reported that miR-141 downregulation-driven EMT in clear cell renal cell carcinoma was correlated to an unfavorable response to sunitinib therapy, and reintroduction of miR-141 in vitro led to EMT reversal and increased sensibility to a hypoxic environment [148]. Also, polycomb group protein BMI1 is an vital regulator of aging, senescence and cancer [149]. With the ability of causing bypass of senescence and immortalization of certain epithelial cell types [150,151], BMI1 is required for self-renewal of stem cells and is often over-expressed in cancer cells. It was discovered that in HDFs, overexpression of miR-141 led to premature senescence via BMI1 targeting and consequence 


\section{Cellular Physiology Cell Physiol Biochem 2016;38:427-448

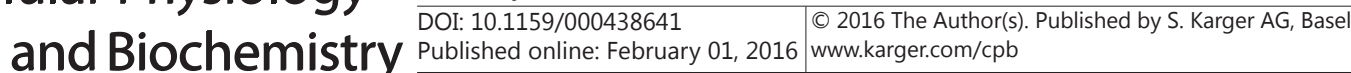 \\ Gao et al.: MiR-141: a Potential Therapeutic Target for Human Cancers}

activation of p16INK4a, p53 and p21 in normal but not in exogenous BMI1-overexpressing cells.

\section{Conclusions for preventing cancer}

Mounting evidence suggests that miRNAs are critical regulators of multifarious diseases including cancer and could be utilized as novel biomarkers for cancer diagnosis, prognosis and treatment. In this review, we described the convincing data presenting miR-141 dysregulation in human malignancies and the mechanisms underlying miR-141mediated tumorigenesis, such as EMT, proliferation, apoptosis, and metastasis [152-154]. Intriguingly, miR-141 could play a dual role as either an oncogene or a tumor-suppressor gene in tumorigenicity of various cancers upon the context. We also discussed the momentous promise of miR-141 as a potential diagnostic and prognostic parameter as well as therapeutic target in personalized therapies of human cancers.

Despite development of early screening and new chemotherapeutic strategies, cancer survival rates achieved no substantially improvement during the past decades. Sensitive and non-invasive biomarkers that can facilitate disease detection, staging, monitoring and prediction of therapeutic outcomes are highly desirable to improve survival rate and help to determine optimized treatment. The time- and pathological-specific expression has raised the possibility of using miR-141 as a novel biomarker from cancer diagnosis to treatment. Meanwhile, therapeutic approaches to introduce miR-141 into manifold cancer cells might be potentially feasible, not only for prohibiting the development of tumorigenes but also in sensitizing cancer cells to chemotherapeutic in the future. Considering the complexity of miR-141 network which involves a variety of signaling pathways, the identification of functional targets needs further verification in more tumor types and clinical tissue samples before the proper application of miR-141 as a molecular biomarker in human cancers.

\section{Acknowledgements}

The work was supported by grants from the National Natural Science Foundation of China (No.81172335 and 81472266) and the Excellent Youth Foundation of Jiangsu Province, China (BK20140032).

\section{Disclosure Statement}

The authors declare that they have no conflicts of interest related to this work.

\section{References}

1 Calin GA, Croce CM: MicroRNA signatures in human cancers. Nat Rev Cancer 2006;6:857-866.

2 Bartel DP: MicroRNAs: Genomics, biogenesis, mechanism, and function. Cell 2004;116:281-297.

3 Croce CM: Causes and consequences of microRNA dysregulation in cancer. Nat Rev Genet 2009;10:704714.

4 Liu Z, Sall A, Yang D: MicroRNA: An emerging therapeutic target and intervention tool. Int J Mol Sci 2008;9:978-999.

5 Calin GA, Sevignani C, Dumitru CD, Hyslop T, Noch E, Yendamuri S, Shimizu M, Rattan S, Bullrich F, Negrini M, Croce CM: Human microRNA genes are frequently located at fragile sites and genomic regions involved in cancers. Proc Natl Acad Sci U S A 2004;101:2999-3004.

6 Park SM, Gaur AB, Lengyel E, Peter ME: The miR-200 family determines the epithelial phenotype of cancer cells by targeting the E-cadherin repressors ZEB1 and ZEB2. Genes Dev 2008;22:894-907.

7 Gregory PA, Bert AG, Paterson EL, Barry SC, Tsykin A, Farshid G, Vadas MA, Khew-Goodall Y, Goodall GJ: The miR-200 family and miR-205 regulate epithelial to mesenchymal transition by targeting ZEB1 and SIP1. Nat Cell Biol 2008;10:593-601. 


\section{Cellular Physiology Cell Physiol Biochem 2016;38:427-448

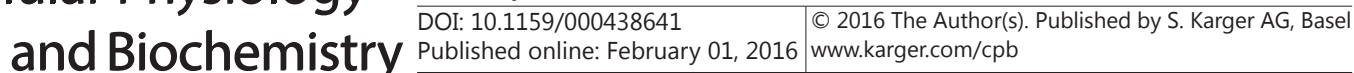 \\ Gao et al.: MiR-141: a Potential Therapeutic Target for Human Cancers}

8 Elson-Schwab I, Lorentzen A, Marshall CJ: MicroRNA-200 family members differentially regulate morphological plasticity and mode of melanoma cell invasion. PLoS One 2010;5.

9 Adam L, Zhong M, Choi W, Qi W, Nicoloso M, Arora A, Calin G, Wang H, Siefker-Radtke A, McConkey D, BarEli M, Dinney C: miR-200 expression regulates epithelial-to-mesenchymal transition in bladder cancer cells and reverses resistance to epidermal growth factor receptor therapy. Clin Cancer Res 2009;15:5060-5072.

10 Jia Y, Yang Y, Zhan Q, Brock MV, Zheng X, Yu Y, Herman JG, Guo M: Inhibition of SOX17 by microRNA 141 and methylation activates the WNT signaling pathway in esophageal cancer. J Mol Diagn 2012;14:577-585.

11 Kriebel S, Schmidt D, Holdenrieder S, Goltz D, Kristiansen G, Moritz R, Fisang C, Muller SC, Ellinger J: Analysis of tissue and serum microRNA expression in patients with upper urinary tract urothelial cancer. PloS One 2015;10:e0117284.

12 Marchini S, Cavalieri D, Fruscio R, Calura E, Garavaglia D, Fuso Nerini I, Mangioni C, Cattoretti G, Clivio L, Beltrame L, Katsaros D, Scarampi L, Menato G, Perego P, Chiorino G, Buda A, Romualdi C, D‘Incalci M: Association between miR-200c and the survival of patients with stage I epithelial ovarian cancer: a retrospective study of two independent tumour tissue collections. Lancet Oncol 2011;12:273-285.

13 Ceppi P, Mudduluru G, Kumarswamy R, Rapa I, Scagliotti GV, Papotti M, Allgayer H: Loss of miR-200c expression induces an aggressive, invasive, and chemoresistant phenotype in non-small cell lung cancer. Mol Cancer Res 2010;8:1207-1216.

14 Chen X, Wang X, Ruan A, Han W, Zhao Y, Lu X, Xiao P, Shi H, Wang R, Chen L, Chen S, Du Q Yang H, Zhang $\mathrm{X}$ : miR-141 is a key regulator of renal cell carcinoma proliferation and metastasis by controlling EphA2 expression. Clin Cancer Res 2014;20:2617-2630.

15 Hur K, Toiyama Y, Takahashi M, Balaguer F, Nagasaka T, Koike J, Hemmi H, Koi M, Boland CR, Goel A: MicroRNA-200c modulates epithelial-to-mesenchymal transition (EMT) in human colorectal cancer metastasis. Gut 2013;62:1315-1326.

16 van Jaarsveld MT, Helleman J, Boersma AW, van Kuijk PF, van Ijcken WF, Despierre E, Vergote I, Mathijssen RH, Berns EM, Verweij J, Pothof J, Wiemer EA: miR-141 regulates KEAP1 and modulates cisplatin sensitivity in ovarian cancer cells. Oncogene 2013;32:4284-4293.

17 Uhlmann S, Zhang JD, Schwager A, Mannsperger H, Riazalhosseini Y, Burmester S, Ward A, Korf U, Wiemann S, Sahin O: miR-200bc/429 cluster targets PLCgamma1 and differentially regulates proliferation and EGFdriven invasion than miR-200a/141 in breast cancer. Oncogene 2010;29:4297-4306.

18 Lee Y, Kim M, Han J, Yeom KH, Lee S, Baek SH, Kim VN: MicroRNA genes are transcribed by RNA polymerase II. EMBO J 2004;23:4051-4060.

19 Denli AM, Tops BBJ, Plasterk RHA, Ketting RF, Hannon GJ: Processing of primary microRNAs by the Microprocessor complex. Nature 2004;432:231-235.

20 Han JJ, Lee Y, Yeom KH, Kim YK, Jin H, Kim VN: The Drosha-DGCR8 complex in primary microRNA processing. Genes Dev 2004;18:3016-3027.

21 Bernstein E, Caudy AA, Hammond SM, Hannon GJ: Role for a bidentate ribonuclease in the initiation step of RNA interference. Nature 2001;409:363-366.

22 Grishok A, Pasquinelli AE, Conte D, Li N, Parrish S, Ha I, Baillie DL, Fire A, Ruvkun G, Mello CC: Genes and mechanisms related to RNA interference regulate expression of the small temporal RNAs that control C. elegans developmental timing. Cell 2001;106:23-34.

23 Hutvagner G, McLachlan J, Pasquinelli AE, Balint E, Tuschl T, Zamore PD: A cellular function for the RNAinterference enzyme Dicer in the maturation of the let-7 small temporal RNA. Science 2001;293:834-838.

24 Ketting RF, Fischer SEJ, Bernstein E, Sijen T, Hannon GJ, Plasterk RHA: Dicer functions in RNA interference and in synthesis of small RNA involved in developmental timing in C. elegans. Genes Dev 2001;15:26542659.

25 Haase AD, Jaskiewicz L, Zhang HD, Laine S, Sack R, Gatignol A, Filipowicz W: TRBP, a regulator of cellular PKR and HIV-1 virus expression, interacts with Dicer and functions in RNA silencing. EMBO Rep 2005;6:961-967.

26 Chendrimada TP, Gregory RI, Kumaraswamy E, Norman J, Cooch N, Nishikura K, Shiekhattar R: TRBP recruits the Dicer complex to Ago2 for microRNA processing and gene silencing. Nature 2005;436:740744.

27 Hutvagner G, Zamore PD: A microRNA in a multiple-turnover RNAi enzyme complex. Science 2002;297:2056-2060. 


\section{Cellular Physiology Cell Physiol Biochem 2016;38:427-448

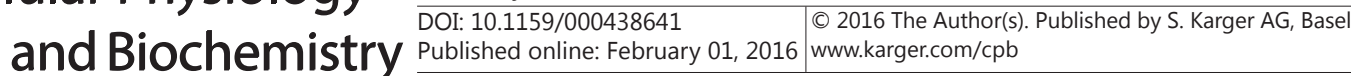 \\ Gao et al.: MiR-141: a Potential Therapeutic Target for Human Cancers}

28 Mourelatos Z, Dostie J, Paushkin S, Sharma A, Charroux B, Abel L, Rappsilber J, Mann M, Dreyfuss G: miRNPs: a novel class of ribonucleoproteins containing numerous microRNAs. Genes Dev 2002;16:720728.

29 Gandhi R: miRNA in multiple sclerosis: Search for novel biomarkers. Mult Scler 2015;21:1095-1103.

30 Lujambio A, Lowe SW: The microcosmos of cancer. Nature 2012;482:347-355.

31 Nelson PT, Hatzigeorgiou AG, Mourelatos Z: miRNP:mRNA association in polyribosomes in a human neuronal cell line. RNA 2004;10:387-394.

32 Meister G, Landthaler M, Patkaniowska A, Dorsett Y, Teng G, Tuschl T: Human Argonaute2 mediates RNA cleavage targeted by miRNAs and siRNAs. Mol Cell 2004;15:185-197.

33 Bartel DP: MicroRNAs: Target recognition and regulatory functions. Cell 2009;136:215-233.

34 Esquela-Kerscher A, Slack FJ: Oncomirs - microRNAs with a role in cancer. Nat Rev Cancer 2006;6:259-269.

35 Bracken CP, Gregory PA, Kolesnikoff N, Bert AG, Wang J, Shannon MF, Goodall GJ: A double-negative feedback loop between ZEB1-SIP1 and the microRNA-200 family regulates epithelial-mesenchymal transition. Cancer Res 2008;68:7846-7854.

36 Zhang L, Huang J, Yang N, Greshock J, Megraw MS, Giannakakis A, Liang S, Naylor TL, Barchetti A, Ward MR, Yao G, Medina A, O’Brien-Jenkins A, Katsaros D, Hatzigeorgiou A, Gimotty PA, Weber BL, Coukos G: microRNAs exhibit high frequency genomic alterations in human cancer. Proc Natl Acad Sci U S A 2006;103:9136-9141.

37 Baylin SB: DNA methylation and gene silencing in cancer. Nat Clin Pract Oncol 2005;2:S4-11.

38 Goll MG, Bestor TH: Eukaryotic cytosine methyltransferases. Annu Rev Biochem 2005;74:481-514.

39 Vrba L, Jensen TJ, Garbe JC, Heimark RL, Cress AE, Dickinson S, Stampfer MR, Futscher BW: Role for DNA methylation in the regulation of miR-200c and miR-141 expression in normal and cancer cells. PloS One 2010;5:e8697.

40 Zhou X, Wang Y, Shan B, Han J, Zhu H, Lv Y, Fan X, Sang M, Liu XD, Liu W: The downregulation of miR200c/141 promotes ZEB1/2 expression and gastric cancer progression. Med Oncol 2015;32:428.

41 Gregory PA, Bracken CP, Smith E, Bert AG, Wright JA, Roslan S, Morris M, Wyatt L, Farshid G, Lim YY, Lindeman GJ, Shannon MF, Drew PA, Khew-Goodall Y, Goodall GJ: An autocrine TGF-beta/ZEB/miR-200 signaling network regulates establishment and maintenance of epithelial-mesenchymal transition. Mol Biol Cell 2011;22:1686-1698.

42 Mohr AM, Bailey JM, Lewallen ME, Liu X, Radhakrishnan P, Yu F, Tapprich W, Hollingsworth MA: MUC1 regulates expression of multiple microRNAs involved in pancreatic tumor progression, including the miR200c/141 cluster. PloS One 2013;8:e73306.

43 Finlay-Schultz J, Cittelly DM, Hendricks P, Patel P, Kabos P, Jacobsen BM, Richer JK, Sartorius CA: Progesterone downregulation of miR-141 contributes to expansion of stem-like breast cancer cells through maintenance of progesterone receptor and Stat5a. Oncogene 2015;34:3676-3687.

44 Xu H, Mei Q, Xiong C, Zhao J: Tumor-suppressing effects of miR-141 in human osteosarcoma. Cell Biochem Biophys 2014;69:319-325.

45 Liu Y, Ding Y, Huang J, Wang S, Ni W, Guan J, Li QS, Zhang YQ Ding YQ Chen B, Chen LH: Mir-141 suppresses the migration and invasion of HCC cells by targeting tiam1. PloS One 2014;9.

46 Samadani U, Porcella A, Pani L, Johnson PF, Burch JB, Pine R, Costa RH: Cytokine regulation of the liver transcription factor hepatocyte nuclear factor-3 beta is mediated by the C/EBP family and interferon regulatory factor 1. Cell Growth Differ 1995;6:879-890.

47 Chen B, Huang T, Jiang J, Lv L, Li H, Xia S: miR-141 suppresses proliferation and motility of gastric cancer cells by targeting HDGF. Mol Cell Biochem 2014;388:211-218.

48 Zhou X, Xia Y, Su J, Zhang G: Down-regulation of miR-141 induced by helicobacter pylori promotes the invasion of gastric cancer by targeting STAT4. Cell Physiol Biochem 2014;33:1003-1012.

49 Zuo QF, Zhang R, Li BS, Zhao YL, Zhuang Y, Yu T, Gong L, Li S, Xiao B, Zou QM: MicroRNA-141 inhibits tumor growth and metastasis in gastric cancer by directly targeting transcriptional co-activator with PDZ-binding motif, TAZ. Cell Death Dis 2015;6:e1623.

50 Maruyama R, Suzuki H, Yamamoto E, Imai K, Shinomura Y: Emerging links between epigenetic alterations and dysregulation of noncoding RNAs in cancer. Tumour Biol 2012;33:277-285.

51 Imanaka Y, Tsuchiya S, Sato F, Shimada Y, Shimizu K, Tsujimoto G: MicroRNA-141 confers resistance to cisplatin-induced apoptosis by targeting YAP1 in human esophageal squamous cell carcinoma. J Hum Genet 2011;56:270-276. 


\section{Cellular Physiology Cell Physiol Biochem 2016;38:427-448

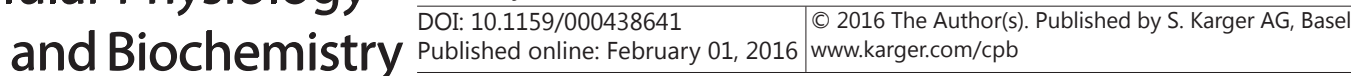 \\ Gao et al.: MiR-141: a Potential Therapeutic Target for Human Cancers}

52 Hu M, Xia M, Chen X, Lin Z, Xu Y, Ma Y, Su L: MicroRNA-141 regulates Smad interacting protein 1 (SIP1) and inhibits migration and invasion of colorectal cancer cells. Dig Dis Sci 2010;55:2365-2372.

53 Poell JB, van Haastert RJ, de Gunst T, Schultz IJ, Gommans WM, Verheul M, Cerisoli F, van Noort PI, Prevost GP, Schaapveld RQ Cuppen E: A functional screen identifies specific microRNAs capable of inhibiting human melanoma cell viability. PloS One 2012;7:e43569.

54 Senanayake U, Das S, Vesely P, Alzoughbi W, Frohlich LF, Chowdhury P, Leuschner I, Hoefler G, Guertl B: MiR-192, miR-194, miR-215, miR-200c and miR-141 are downregulated and their common target acvr2b is strongly expressed in renal childhood neoplasms. Carcinogenesis 2012;33:1014-1021.

55 Yu XY, Zhang Z, Liu J, Zhan B, Kong CZ: MicroRNA-141 is downregulated in human renal cell carcinoma and regulates cell survival by targeting CDC25B. Onco Targets Ther 2013;6:349-354.

56 Nakada C, Matsuura K, Tsukamoto Y, Tanigawa M, Yoshimoto T, Narimatsu T, Nguyen LT, Hijiya N, Uchida T, Sato F, Mimata H, Seto M, Moriyama M: Genome-wide microrna expression profiling in renal cell carcinoma: Significant down-regulation of miR-141 and miR-200c. J Pathol 2008;216:418-427.

57 Zhang HL, Qin XJ, Cao DL, Zhu Y, Yao XD, Zhang SL, Dai B, Ye DW: An elevated serum miR-141 level in patients with bone-metastatic prostate cancer is correlated with more bone lesions. Asian J Androl 2013;15:231-235.

58 Zhang L, Deng T, Li X, Liu H, Zhou H, Ma J, Wu M, Zhou M, Shen S, Li X, Niu Z, Zhang W, Shi L, Xiang B, Lu J, Wang L, Li D, Tang H, Li G: microRNA-141 is involved in a nasopharyngeal carcinoma-related genes network. Carcinogenesis. 2010; 31(4):559-566.

59 Rasheed SA, Teo CR, Beillard EJ, Voorhoeve PM, Casey PJ: MicroRNA-182 and microRNA-200a control G-protein subunit $\alpha$-13 (GNA13) expression and cell invasion synergistically in prostate cancer cells. J Biol Chem 2013;288:7986-7995.

60 Xiao J, Gong AY, Eischeid AN, Chen D, Deng C, Young CY, Chen XM: MiR-141 modulates androgen receptor transcriptional activity in human prostate cancer cells through targeting the small heterodimer partner protein. Prostate 2012;72:1514-1522.

61 Dimri M, Carroll JD, Cho JH, Dimri GP: microRNA-141 regulates BMI1 expression and induces senescence in human diploid fibroblasts. Cell Cycle 2013;12:3537-3546.

62 Mei Z, He Y, Feng J, Shi J, Du Y, Qian L, Huang Q, Jie Z: MicroRNA-141 promotes the proliferation of nonsmall cell lung cancer cells by regulating expression of PHLPP1 and PHLPP2. FEBS Lett 2014;588:30553061.

63 Cantley LC: The phosphoinositide 3-kinase pathway. Science 2002;296:1655-1657.

64 O’Neill AK, Niederst MJ, Newton AC: Suppression of survival signalling pathways by the phosphatase PHLPP. FEBS J 2013;280:572-583.

65 Huang Y, Tong J, He F, Yu X, Fan L, Hu J, Tan J, Chen Z: miR-141 regulates TGF- $\beta 1$-induced epithelialmesenchymal transition through repression of HIPK2 expression in renal tubular epithelial cells. Int J Mol Med 2015;35:311-318.

66 Thiery JP: Epithelial-mesenchymal transitions in tumour progression. Nat Rev Cancer 2002;2:442-454.

67 Neves R, Scheel C, Weinhold S, Honisch E, Iwaniuk KM, Trompeter HI, Niederacher D, Wernet P, Santourlidis S, Uhrberg M: Role of DNA methylation in miR-200c/141 cluster silencing in invasive breast cancer cells. BMC Res Notes 2010;3:219.

68 Thiery JP, Acloque H, Huang RY, Nieto MA: Epithelial-mesenchymal transitions in development and disease. Cell 2009;139:871-890.

69 Liang HH, Wei PL, Hung CS, Wu CT, Wang W, Huang MT, Chang YJ: MicroRNA-200a/b influenced the therapeutic effects of curcumin in hepatocellular carcinoma (HCC) cells. Tumour Biol 2013;34:3209-3218.

70 Bindels S, Mestdagt M, Vandewalle C, Jacobs N, Volders L, Noel A, van Roy F, Berx G, Foidart JM, Gilles C: Regulation of vimentin by SIP1 in human epithelial breast tumor cells. Oncogene 2006;25:4975-4985.

71 Mizuguchi Y, Specht S, Lunz JG, 3rd, Isse K, Corbitt N, Takizawa T, Demetris AJ: Cooperation of p300 and PCAF in the control of microRNA 200c/141 transcription and epithelial characteristics. PloS One 2012;7:e32449.

72 Bedford DC, Kasper LH, Fukuyama T, Brindle PK: Target gene context influences the transcriptional requirement for the KAT3 family of CBP and p300 histone acetyltransferases. Epigenetics 2010;5:9-15.

73 Gayther SA, Batley SJ, Linger L, Bannister A, Thorpe K, Chin SF, Daigo Y, Russell P, Wilson A, Sowter HM, Delhanty JD, Ponder BA, Kouzarides T, Caldas C: Mutations truncating the EP300 acetylase in human cancers. Nat Cenet 2000;24:300-303. 


\section{Cellular Physiology Cell Physiol Biochem 2016;38:427-448 \begin{tabular}{l|l|l|l|}
\hline DOI: 10.1159/000438641 & C 2016 The Author(s). Published by S. Karger AG, Basel \\
anww.karger.com/cpb
\end{tabular} \\ Gao et al.: MiR-141: a Potential Therapeutic Target for Human Cancers}

74 Yang J, Weinberg RA: Epithelial-mesenchymal transition: At the crossroads of development and tumor metastasis. Dev Cell 2008;14:818-829.

75 Kent OA, Mullendore M, Wentzel EA, Lopez-Romero P, Tan AC, Alvarez H, West K, Ochs MF, Hidalgo M, Arking DE, Maitra A, Mendell JT: A resource for analysis of microRNA expression and function in pancreatic ductal adenocarcinoma cells. Cancer Biol Ther 2009;8:2013-2024.

76 Meng FY, Henson R, Lang M, Wehbe H, Maheshwari S, Mendell JT, Jiang JM, Schmittgen TD, Patel T: Involvement of human micro-RNA in growth and response to chemotherapy in human cholangiocarcinoma cell lines. Gastroenterology 2006;130:2113-2129.

77 Mateescu B, Batista L, Cardon M, Gruosso T, de Feraudy Y, Mariani O, Nicolas A, Meyniel JP, Cottu P, SastreGarau X, Mechta-Grigoriou F: miR-141 and miR-200a act on ovarian tumorigenesis by controlling oxidative stress response. Net Med 2011;17:1627-1635.

78 Morales-Prieto DM, Schleussner E, Markert UR: Reduction in miR-141 is induced by leukemia inhibitory factor and inhibits proliferation in choriocarcinoma cell line JEG-3. Am J Reprod Immunol 2011;66 Suppl 1:57-62.

79 Kanai F, Marignani PA, Sarbassova D, Yagi R, Hall RA, Donowitz M, Hisaminato A, Fujiwara T, Ito Y, Cantley LC, Yaffe MB: TAZ: a novel transcriptional co-activator regulated by interactions with 14-3-3 and PDZ domain proteins. EMBO J 2000;19:6778-6791.

80 Cui CB, Cooper LF, Yang X, Karsenty G, Aukhil I: Transcriptional coactivation of bone-specific transcription factor Cbfa1 by TAZ. Mol Cell Biol 2003;23:1004-1013.

81 Walworth NC: Cell-cycle checkpoint kinases: Checking in on the cell cycle. Curr Opin Cell Biol 2000;12:697704.

82 Zhou M, Xu XJ, Zhou HD, Liu HY, He JJ, Li XL, Peng C, Xiong W, Fan SQ, Lu JH, Ouyang J, Shen SR, Xiang B, Li GY: BRD2 is one of BRD7-interacting proteins and its over-expression could initiate apoptosis. Mol Cell Biochem 2006;292:205-212.

83 Gao QL, Ye F, Xia X, Xing H, Lu YP, Zhou JF, Ma D: Correlation between PTEN expression and PI3K/Akt signal pathway in endometrial carcinoma. J Huazhong Univ Sci Technolog Med Sci 2009;29:59-63.

84 Liu XG, Zhu WY, Huang YY, Ma LN, Zhou SQ, Wang YK, Zeng F, Zhou JH, Zhang YK: High expression of serum miR-21 and tumor miR-200c associated with poor prognosis in patients with lung cancer. Med Oncol 2012;29:618-626.

85 Fitzgerald JS, Poehlmann TG, Schleussner E, Markert UR: Trophoblast invasion: the role of intracellular cytokine signalling via signal transducer and activator of transcription 3 (STAT3). Hum Reprod Update 2008;14:335-344.

86 Poehlmann TG, Fitzgerald JS, Meissner A, Wengenmayer T, Schleussner E, Friedrich K, Markert UR: Trophoblast invasion: tuning through LIF, signalling via Stat3. Placenta 2005;26 Suppl A:S37-41.

87 Zhao G, Wang B, Liu Y, Zhang JG, Deng SC, Qin Q Tian K, Li X, Zhu S, Niu Y, Gong Q, Wang CY: miRNA-141, downregulated in pancreatic cancer, inhibits cell proliferation and invasion by directly targeting MAP4K4. Mol Cancer Ther 2013;12:2569-2580.

88 Hu Y, Leo C, Yu S, Huang BC, Wang H, Shen M, Luo Y, Daniel-Issakani S, Payan DG, Xu X: Identification and functional characterization of a novel human misshapen/Nck interacting kinase-related kinase, hMINK beta. J Biol Chem 2004;279:54387-54397.

89 Hyun S, Lee JH, Jin H, Nam J, Namkoong B, Lee G, Chung J, Kim VN: Conserved MicroRNA miR-8/miR-200 and its target USH/FOG2 control growth by regulating PI3K. Cell 2009;139:1096-1108.

90 Zhu ZM, Xu YF, Su QJ, Du JD, Tan XL, Tu YL, Tan JW, Jiao HB: Prognostic significance of microRNA-141 expression and its tumor suppressor function in human pancreatic ductal adenocarcinoma. Mol Cell Biochem 2014;388:39-49.

91 Sudol M, Shields DC, Farooq A: Structures of YAP protein domains reveal promising targets for development of new cancer drugs. Semin Cell Dev Biol 2012;23:827-833.

92 Seol W, Choi HS, Moore DD: An orphan nuclear hormone receptor that lacks a DNA binding domain and heterodimerizes with other receptors. Science 1996;272:1336-1339.

93 Chiao JW, Wu H, Ramaswamy G, Conaway CC, Chung FL, Wang L, Liu D: Ingestion of an isothiocyanate metabolite from cruciferous vegetables inhibits growth of human prostate cancer cell xenografts by apoptosis and cell cycle arrest. Carcinogenesis 2004;25:1403-1408. 


\section{Cellular Physiology Cell Physiol Biochem 2016;38:427-448

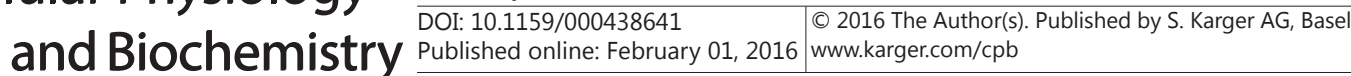 \\ Gao et al.: MiR-141: a Potential Therapeutic Target for Human Cancers}

94 Xiao D, Singh SV: Phenethyl isothiocyanate-induced apoptosis in p53-deficient PC-3 human prostate cancer cell line is mediated by extracellular signal-regulated kinases. Cancer Res 2002;62:3615-3619.

95 Smith TJ, Guo Z, Guengerich FP, Yang CS: Metabolism of 4-(methylnitrosamino)-1-(3-pyridyl)-1-butanone (NNK) by human cytochrome P450 1A2 and its inhibition by phenethyl isothiocyanate. Carcinogenesis 1996;17:809-813.

96 Gao TY, Furnari F, Newton AC: PHLPP: a phosphatase that directly dephosphorylates Akt, promotes apoptosis, and suppresses tumor growth.. Mol Cell 2005;18:13-24.

97 Lin L, Liang H, Wang Y, Yin X, Hu Y, Huang J, Ren T, Xu H, Zheng L, Chen X: microRNA-141 inhibits cell proliferation and invasion and promotes apoptosis by targeting hepatocyte nuclear factor-3 $\beta$ in hepatocellular carcinoma cells. BMC Cancer 2014;14:879.

98 Parri M, Chiarugi P: Rac and Rho GTPases in cancer cell motility control. Cell Commun Signal 2010;8:23

99 Mao J, Xu Z, Fang Y, Wang H, Xu J, Ye J, Zheng S, Zhu Y: Hepatoma-derived growth factor involved in the carcinogenesis of gastric epithelial cells through promotion of cell proliferation by Erk1/2 activation. Cancer Sci 2008;99:2120-2127.

100 Bullock MD, Sayan AE, Packham GK, Mirnezami AH: MicroRNAs: critical regulators of epithelial to mesenchymal (EMT) and mesenchymal to epithelial transition (MET) in cancer progression. Biol Cell 2012;104:3-12.

101 Wu SM, Ai HW, Zhang DY, Han XQ Pan Q, Luo FL, Zhang XL: MiR-141 targets ZEB2 to suppress HCC progression. Tumour Biol 2014;35:9993-9997.

102 Watson CJ: Stat transcription factors in mammary gland development and tumorigenesis. J Mammary Gland Biol 2001;6:115-127.

103 Xu L, Li Q, Xu D, Wang Q, An Y, Du Q, Zhang J, Zhu Y, Miao Y: hsa-miR-141 downregulates TM4SF1 to inhibit pancreatic cancer cell invasion and migration. Int J Oncol 2014;44:459-466.

104 Wright MD, Ni J, Rudy GB: The L6 membrane proteins - a new four-transmembrane superfamily. Protein Sci 2000;9:1594-1600.

105 Mitchell PS, Parkin RK, Kroh EM, Fritz BR, Wyman SK, Pogosova-Agadjanyan EL, Peterson A, Noteboom J, O'Briant KC, Allen A, Lin DW, Urban N, Drescher CW, Knudsen BS, Stirewalt DL, Gentleman R, Vessella RL, Nelson PS, Martin DB, Tewari M: Circulating micrornas as stable blood-based markers for cancer detection. Proc Natl Acad Sci U S A 2008;105:10513-10518.

106 Chen PC, Cheng HC, Yang SF, Lin CW, Tang CH: The CCN family proteins: Modulators of bone development and novel targets in bone-associated tumors. Biomed Res Int 2014

107 Horng CT, Shieh PC, Tan TW, Yang WH, Tang CH: Paeonol suppresses chondrosarcoma metastasis through up-regulation of miR-141 by modulating PKC $\delta$ and c-Src signaling pathway. Int J Mol Sci 2014;15:1176011772.

108 Suarez Y, Sessa WC: MicroRNAs as novel regulators of angiogenesis. Circ Res 2009;104:442-454.

109 Mammoto A, Connor KM, Mammoto T, Yung CW, Huh D, Aderman CM, Mostoslavsky G, Smith LE, Ingber DE: A mechanosensitive transcriptional mechanism that controls angiogenesis. Nature 2009;457:1103-1108.

110 Fish JE, Santoro MM, Morton SU, Yu S, Yeh RF, Wythe JD, Ivey KN, Bruneau BG, Stainier DY, Srivastava D: miR-126 regulates angiogenic signaling and vascular integrity. Dev Cell 2008;15:272-284.

111 Tejero R, Navarro A, Campayo M, Vinolas N, Marrades RM, Cordeiro A, Ruiz-Martinez M, Santasusagna S, Molins L, Ramirez J, Monzo M: miR-141 and miR-200c as markers of overall survival in early stage nonsmall cell lung cancer adenocarcinoma. PloS One 2014;9:e101899.

112 Bremnes RM, Camps C, Sirera R: Angiogenesis in non-small cell lung cancer: the prognostic impact of neoangiogenesis and the cytokines VEGF and bFGF in tumours and blood. Lung Cancer 2006;51:143-158.

113 Xue W, Krasnitz A, Lucito R, Sordella R, VanAelst L, Cordon-Cardo C, Singer S, Kuehnel F, Wigler M, Powers S, Zender L, Lowe SW: DLC1 is a chromosome 8p tumor suppressor whose loss promotes hepatocellular carcinoma. Genes Dev 2008;22:1439-1444.

114 Wong CM, Yam JWP, Ching YP, Yau TO, Leung THY, Jin DY, Ng IOL: Rho GTPase-activating protein deleted in liver cancer suppresses cell proliferation and invasion in hepatocellular carcinoma. Cancer Res 2005;65:8861-8868.

115 Banaudha K, Kaliszewski M, Korolnek T, Florea L, Yeung ML, Jeang KT, Kumar A: MicroRNA silencing of tumor suppressor DLC-1 promotes efficient hepatitis C virus replication in primary human hepatocytes. Hepatology 2011;53:53-61. 


\section{Cellular Physiology Cell Physiol Biochem 2016;38:427-448

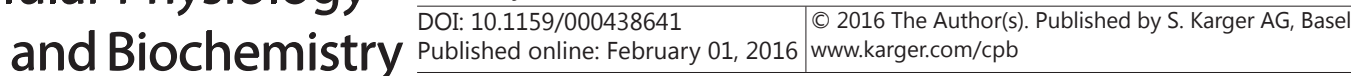 \\ Gao et al.: MiR-141: a Potential Therapeutic Target for Human Cancers}

116 Fan J, Xing Y, Wen X, Jia R, Ni H, He J, Ding X, Pan H, Qian G, Ge S, Hoffman AR, Zhang H, Fan X: Long noncoding RNA ROR decoys gene-specific histone methylation to promote tumorigenesis. Genome Biol 2015;16:139.

117 Chiyomaru T, Fukuhara S, Saini S, Majid S, Deng G, Shahryari V, Chang I, Tanaka Y, Enokida H, Nakagawa M, Dahiya R, Yamamura S: Long non-coding RNA hotair is targeted and regulated by miR-141 in human cancer cells. J Biol Chem 2014;289:12550-12565.

118 Gupta RA, Shah N, Wang KC, Kim J, Horlings HM, Wong DJ, Tsai MC, Hung T, Argani P, Rinn JL, Wang YL, Brzoska P, Kong B, Li R, West RB, van de Vijver MJ, Sukumar S, Chang HY: Long non-coding RNA HOTAIR reprograms chromatin state to promote cancer metastasis. Nature 2010;464:1071-U1148.

119 Kim K, Jutooru I, Chadalapaka G, Johnson G, Frank J, Burghardt R, Kim S, Safe S: HOTAIR is a negative prognostic factor and exhibits pro-oncogenic activity in pancreatic cancer. Oncogene 2013;32:1616-1625.

120 Zhou X, Ye F, Yin C, Zhuang Y, Yue G, Zhang G: The interaction between miR-141 and lncRNA-H19 in regulating cell proliferation and migration in gastric cancer. Cell Biochem Biophys 2015;36:1440-1452.

121 Laurent G, Solari F, Mateescu B, Karaca M, Castel J, Bourachot B, Magnan C, Billaud M, Mechta-Grigoriou F: Oxidative stress contributes to aging by enhancing pancreatic angiogenesis and insulin signaling. Cell Metab 2008;7:113-124.

122 Toullec A, Gerald D, Despouy G, Bourachot B, Cardon M, Lefort S, Richardson M, Rigaill G, Parrini MC, Lucchesi C, Bellanger D, Stern MH, Dubois T, Sastre-Garau X, Delattre O, Vincent-Salomon A, MechtaGrigoriou F: Oxidative stress promotes myofibroblast differentiation and tumour spreading. EMBO Mol Med 2010;2:211-230.

123 Pani G, Galeotti T, Chiarugi P: Metastasis: Cancer cell's escape from oxidative stress. Cancer Metastasis Rev 2010;29:351-378.

124 Hui L, Bakiri L, Mairhorfer A, Schweifer N, Haslinger C, Kenner L, Komnenovic V, Scheuch H, Beug H, Wagner EF: p38alpha suppresses normal and cancer cell proliferation by antagonizing the JNK-c-Jun pathway. Nat Genet 2007;39:741-749.

125 Kim EK, Choi EJ: Pathological roles of MAPK signaling pathways in human diseases. Biochim Biophys Acta 2010;1802:396-405.

126 Gibbons DL, Lin W, Creighton CJ, Rizvi ZH, Gregory PA, Goodall GJ, Thilaganathan N, Du L, Zhang Y, Pertsemlidis A, Kurie JM: Contextual extracellular cues promote tumor cell emt and metastasis by regulating miR-200 family expression. Genes Dev 2009;23:2140-2151.

127 Wiklund ED, Bramsen JB, Hulf T, Dyrskjot L, Ramanathan R, Hansen TB, Villadsen SB, Gao S, Ostenfeld MS, Borre M, Peter ME, Orntoft TF, Kjems J, Clark SJ: Coordinated epigenetic repression of the miR-200 family and miR-205 in invasive bladder cancer. Int J Cancer 2011;128:1327-1334.

128 Ke XS, Liu CM, Liu DP, Liang CC: MicroRNAs: Key participants in gene regulatory networks. Curr Opin Chem Biol 2003;7:516-523.

129 Wszolek MF, Rieger-Christ KM, Kenney PA, Gould JJ, Silva Neto B, Lavoie AK, Logvinenko T, Libertino JA, Summerhayes IC: A Microrna expression profile defining the invasive bladder tumor phenotype. Urol Oncol 2011;29:794-801. e1.

130 Cheng H, Zhang L, Cogdell DE, Zheng H, Schetter AJ, Nykter M, Harris CC, Chen K, Hamilton SR, Zhang W: Circulating plasma miR-141 is a novel biomarker for metastatic colon cancer and predicts poor prognosis. PloS One 2011;6:e17745.

131 Nam EJ, Yoon H, Kim SW, Kim H, Kim YT, Kim JH, Kim JW, Kim S: MicroRNA expression profiles in serous ovarian carcinoma. Clin Cancer Res 2008;14:2690-2695.

132 Leo S, Accettura C, Lorusso V: Castration-resistant prostate cancer: Targeted therapies. Chemotherapy 2011;57:115-127.

133 Mazzola CRE, Ghoneim T, Shariat SF: Emerging biomarkers for the diagnosis, staging and prognosis of prostate cancer. Prog Urol 2011;21:1-10.

134 Yaman Agaoglu F, Kovancilar M, Dizdar Y, Darendeliler E, Holdenrieder S, Dalay N, Gezer U: Investigation of miR-21, miR-141, and miR-221 in blood circulation of patients with prostate cancer. Tumour Biol 2011;32:583-588.

135 Giovannucci E, Rimm EB, Liu Y, Stampfer MJ, Willett WC: A prospective study of cruciferous vegetables and prostate cancer. Cancer Epidemiol Biomarkers Prev 2003;12:1403-1409. 


\section{Cellular Physiology Cell Physiol Biochem 2016;38:427-448

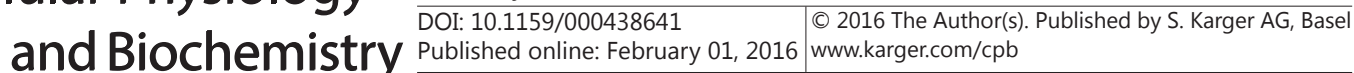 \\ Gao et al.: MiR-141: a Potential Therapeutic Target for Human Cancers}

136 Wang LG, Beklemisheva A, Liu XM, Ferrari AC, Feng J, Chiao JW: Dual action on promoter demethylation and chromatin by an isothiocyanate restored GSTP1 silenced in prostate cancer. Mol Carcinog 2007;46:2431.137

137 Xiao D, Lew KL, Zeng Y, Xiao H, Marynowski SW, Dhir R, Singh SV: Phenethyl isothiocyanate-induced apoptosis in PC-3 human prostate cancer cells is mediated by reactive oxygen species-dependent disruption of the mitochondrial membrane potential. Carcinogenesis 2006;27:2223-2234.

138 Bryant RJ, Pawlowski T, Catto JW, Marsden G, Vessella RL, Rhees B, Kuslich C, Visakorpi T, Hamdy FC: Changes in circulating microRNA levels associated with prostate cancer. Br J Cancer 2012;106:768-774.

139 Nguyen HC, Xie W, Yang M, Hsieh CL, Drouin S, Lee GS, Kantoff PW: Expression differences of circulating microRNAs in metastatic castration resistant prostate cancer and low-risk, localized prostate cancer. Prostate 2013;73:346-354.

140 Brase JC, Johannes M, Schlomm T, Falth M, Haese A, Steuber T, Beissbarth T, Kuner R, Sultmann H: Circulating miRNAs are correlated with tumor progression in prostate cancer. Int J Cancer 2011;128:608616.

141 van Bokhoven A, Varella-Garcia M, Korch C, Johannes WU, Smith EE, Miller HL, Nordeen SK, Miller GJ, Lucia MS: Molecular characterization of human prostate carcinoma cell lines. Prostate 2003;57:205-225.

142 Dorris ER, Smyth P, O‘Leary JJ, Sheils O: MIR141 Expression Differentiates Hashimoto Thyroiditis from PTC and Benign Thyrocytes in Irish Archival Thyroid Tissues. Front Endocrinol (Lausanne) 2012;3:102.

143 Braun J, Hoang-Vu C, Dralle H, Huttelmaier S: Downregulation of microRNAs directs the emt and invasive potential of anaplastic thyroid carcinomas. Oncogene 2010;29:4237-4244.

144 Zhang XL, Li P, Rong MH, He RQ, Hou XX, Xie Y, Chen G: MicroRNA-141 is a biomarker for progression of squamous cell carcinoma and adenocarcinoma of the lung: Clinical analysis of 125 patients. Tohoku J Exp Med 2015;235:161-169.

145 Li H, Xu HY, Shen HL, Li H: microRNA-106a modulates cisplatin sensitivity by targeting PDCD4 in human ovarian cancer cells. Oncol Lett 2014;7:183-188.

146 Zhou XY, Su J, Zhu L, Zhang GX: Helicobacter pylori modulates cisplatin sensitivity in gastric cancer by down-regulating miR-141 expression. Helicobacter 2014;19:174-181.

147 Jaramillo MC, Zhang DD: The emerging role of the Nrf2-Keap1 signaling pathway in cancer. Genes Dev 2013;27:2179-2191.

148 Berkers J, Govaere O, Wolter P, Beuselinck B, Schoffski P, van Kempen LC, Albersen M, Van den Oord J, Roskams T, Swinnen J, Joniau S, Van Poppel H, Lerut E: A possible role for microRNA-141 down-regulation in sunitinib resistant metastatic clear cell renal cell carcinoma through induction of epithelial-tomesenchymal transition and hypoxia resistance. J Urol 2013;189:1930-1938.

149 Baker DJ, Wijshake T, Tchkonia T, LeBrasseur NK, Childs BG, van de Sluis B, Kirkland JL, van Deursen JM: Clearance of p16ink4a-positive senescent cells delays ageing-associated disorders. Nature 2011;479:232236.

150 Bracken AP, Kleine-Kohlbrecher D, Dietrich N, Pasini D, Gargiulo G, Beekman C, Theilgaard-Monch K, Minucci S, Porse BT, Marine JC, Hansen KH, Helin K: The Polycomb group proteins bind throughout the INK4A-ARF locus and are disassociated in senescent cells. Genes Dev 2007;21:525-530.

151 Itahana K, Zou Y, Itahana Y, Martinez JL, Beausejour C, Jacobs JJL, van Lohuizen M, Band V, Campisi J, Dimri GP: Control of the replicative life span of human fibroblasts by p16 and the polycomb protein Bmi-1. Mol Cell Biol 2003;23:389-401.

152 Tang W, Qin J, Tang J, Zhang H, Zhou Z, Li B, Geng Q, Wu W, Xia Y, Xu X: Aberrant reduction of miR-141 increased cd47/cul3 in hirschsprung's disease. Cell Biochem Biophys 2013;32:1655-1667.

153 Che H, Sun LH, Guo F, Niu HF, Su XL, Bao YN, Fu ZD, Liu HL, Hou X, Yang BF, Ai J: Expression of amyloidassociated miRNAs in both the forebrain cortex and hippocampus of middle-aged rat. Cell Biochem Biophys 2014;33:11-22.

154 Li H, Tang J, Lei H, Cai P, Zhu H, Li B, Xu X, Xia Y, Tang W: Decreased miR-200a/141 suppress cell migration and proliferation by targeting pten in hirschsprung's disease. Cell Biochem Biophys 2014;34:543-553. 